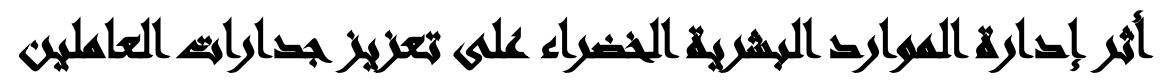

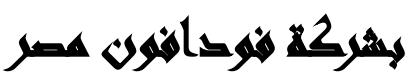

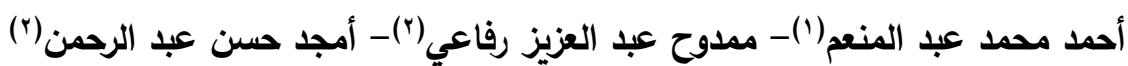

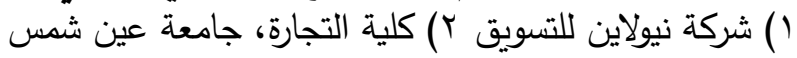

\title{
المستخليس
}

الهدف من البحث هو التعرف على واقع إدارة الموارد البشرية الخضراء, والوقوف على

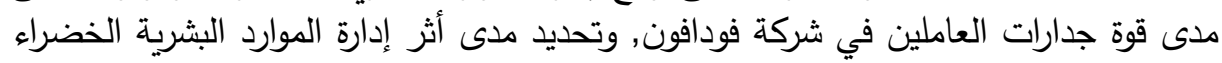

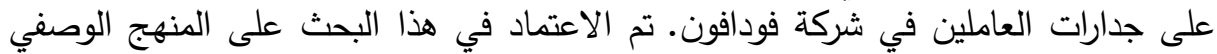

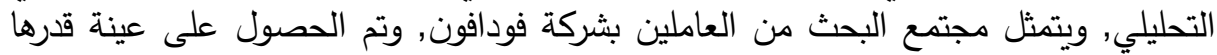

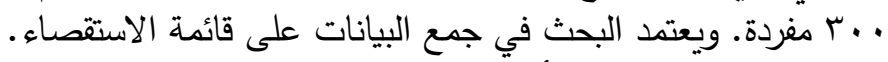

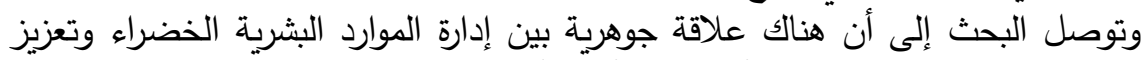

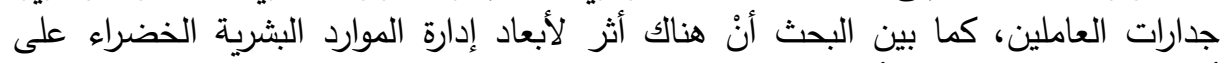

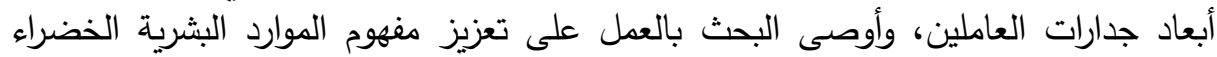
وتعزيز مفهوم الجدارات الإدارية. الكلمات المفتاحية: الموارد البشرية الخضراءية الخراء، إدارة الموارد البشرية، جدارات العاملين، مفهوم

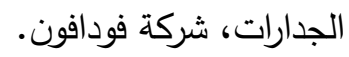

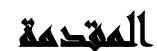

إن إدارة الموارد البشرية الخضراء تعمل على تشجيع الاستخدام الأمثل للموارد البشرية في

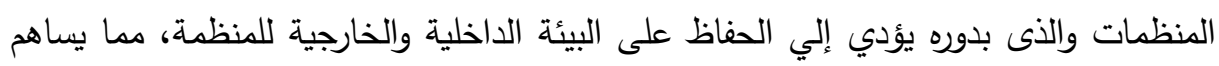
في خفض التكاليف وتحقيق أعلى عائد متوقع لهذه المنظمات. لذلك فإن الوعى المتزايد

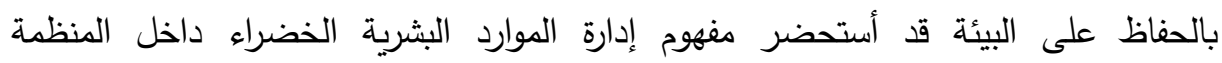
.(ShavangRen, \& Susan 2017, P. 2)

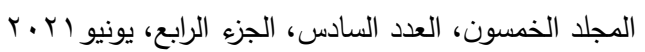

$$
\begin{aligned}
& \text { الترقيم الدولي 0826-0 1110 119 }
\end{aligned}
$$


ويرتبط مفهوم الجدارة ارتباطا وثيقا بإدارة الموارد البشرية, حيث يرتبط ذلك مباشرة بالهدف

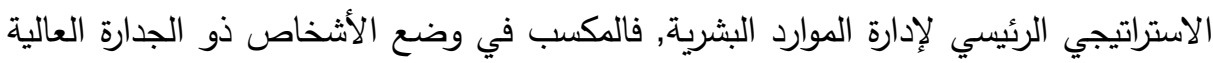

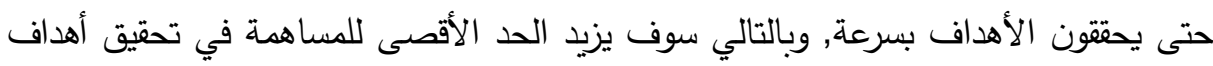
• الثركة (Sienkiewicz, 2014, p. 207)

إن مدخل الجدارة يقدم للموارد البشرية طريقة تصلح تماما للتطبيق بثكل متميز في

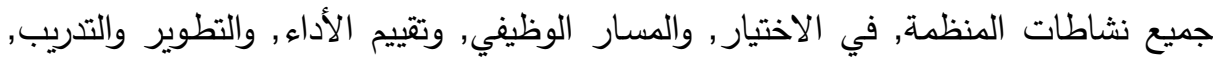

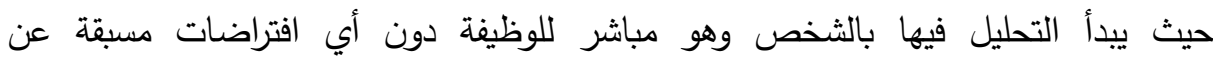

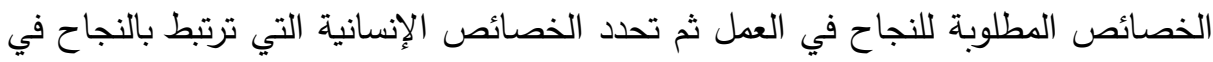
العمل, فالجدارات أصبحت طرق دقيقة لتمييز ذوي الأداء المتميز عن متوسطي الأداء أو الونائه

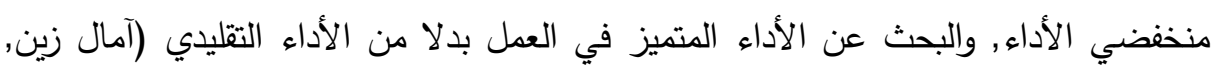

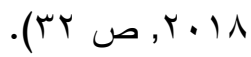
ونظرا لوعي شركة فودافون مصر بقضايا البيئة، فقد وضعت الثركة خططها الهادفة إلى صلى معالجة القضايا البيئية العالمية التي تواجه النظام البيئي. وقد وجد ولدئ أن الاتجاه لإدارة أكثر

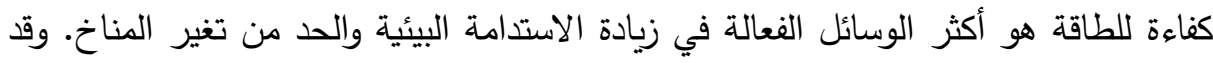

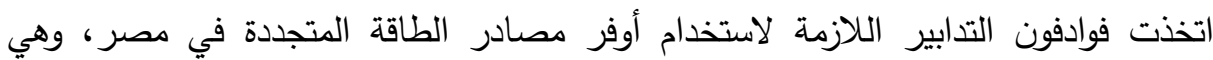
الثمس، حيث أن استخدام الطاقة المتجددة هو الوسيلة الرئيسية لتحقيق استخدام أكثر كفاءة للطاقة. ويسعى الباحث من خلال هذا البحث إلى تفسير تأثير إدارة الموارد البشرية الخضراء

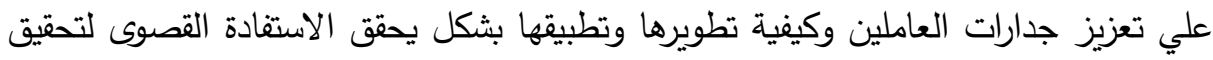

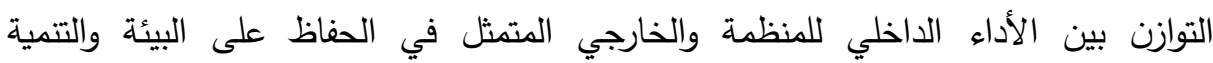




\section{And ILAn}

إن واقع شركات الاتصالات يواجه العديد من التحديات وتتوع المشكلات التنظيمية وزيادة حدة المنافسة، والتغيرات المستمرة في احتياجات العاملين ومتطلباتهم، كما أن الأساليب والطرق التقليدية لم تعد ملائمة الآن في ظل الظروف والمتغيرات البيئية المعاصرة (تامر طلعت, (Y · r, ص r I). هذا, بجانب افتقار بعض المديرين بشركات الاتصالات إلى إدراك

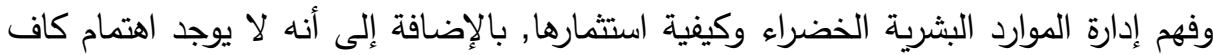
بجدارات العاملين, ويظهر ذلك جليا في الظواهر التالية: عدم استفادة بعض العاملين من الدورات التدريبية لعدم تتاسبها مع وظيفته. سفر بعض الكوادر والعقول البشرية ذات الخبرة العالية للعمل بالخارج للاستفادة بالمقابل

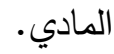
• عدم حرص الرؤوساء علي منح الحوافز او المكافأت الفورية علي العمل الابداعي.

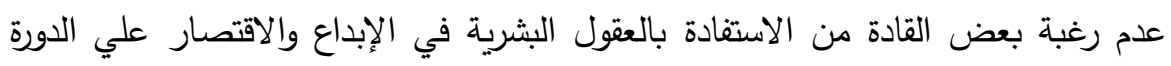

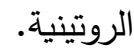
الاعتماد في عملية الترقية علي مدة الخدمة وليس علي عامل الكفاءة. واستتادا لما تقدم جاءت فكرة البحث الحالي في محاولة لمعالجة مشكلات واقعية تؤثر علئر بشكل كبير على الثركات المصرية بصورة عامة, وفي شركة فودافون بصورة خاصة. ولثعور الباحث بقلة الكتابات والدراسات السابقة وعدم تصدي الباحثين ولاسيما في شركة فودافون

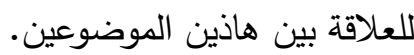

\section{أسهولة المهنه}

لذا, تتمثل مشكلة البحث في التعرف علي الآثار الإدارية في الاهتمام بإدارة الموارد

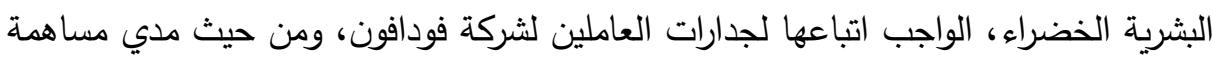

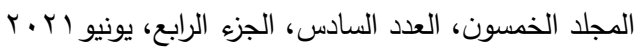

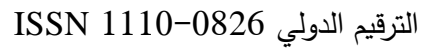


إدارة الموارد البشرية الخضراء بأبعاده في تحقيق أهداف الثركة. وعليه, يمكن تحديد مشكلة

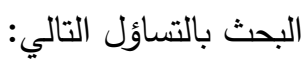

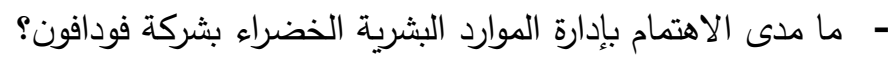
- ما مدى جدارات العاملين بشركة فودافون؟ - ما أثر إدارة الموارد البشرية الخضراء في جدارات العاملين بشركة فودافون؟

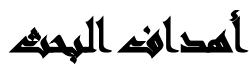

$$
\text { يهدف البحث إلى ما يلي: }
$$

تحديد مدى الاهتمام بإدارة الموارد البشرية الخضراء بشركة فودافون. تحديد مدى جدارات العاملين بشركة فودافون.

تحديد مدى أثر إدارة الموارد البشرية الخضراء على جدارات العاملين في شركة فودافون.

\section{أهمية المهمث}

ترجع أهمية البحث فيما يلي:

الأهمية العلمية: تتاول البحث موضوع إدارة الموارد البشرية الخضراء وجدارات العاملين وهما

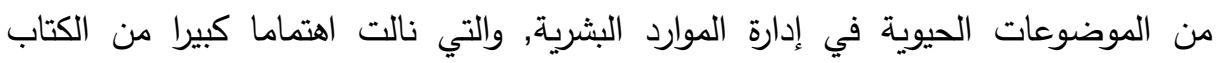

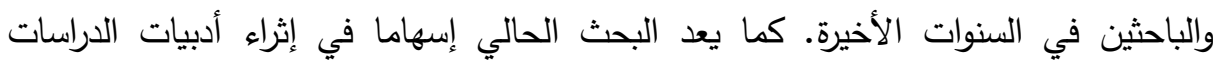

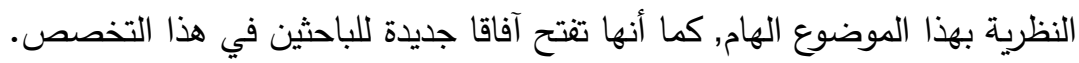
الأهمية العملية: تكمن أهمية البحث في أنه يتتاول موضوعا إداريا أصبح يمس جوهر أعمال

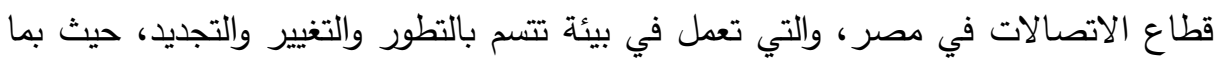

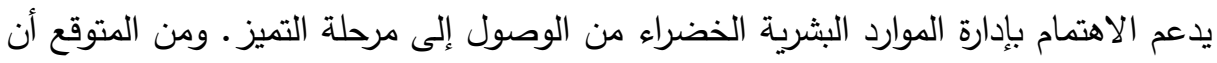

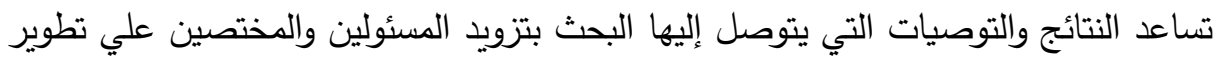
جدارات العاملين لشركة فودافون بمنظور جديد, ويمكن أن تساعد نتائج هذا البحث على 368

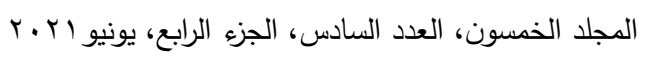

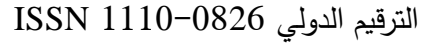


استخلاص العديد من المؤشرات المفيدة في رسم وإعادة تصميم السياسات الإدارية المستخدمة في إدارة الموارد البشرية.

\section{هروغ المهشه}

الفرض الرئيسي: "يوجد أثر جوهري لإدارة الموارد البثرية الخضراء على جدارات العاملين بثركة فودافون". وينبثق من هذا الفرض عدة فروض فرعية, هي:

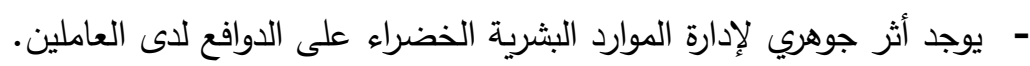

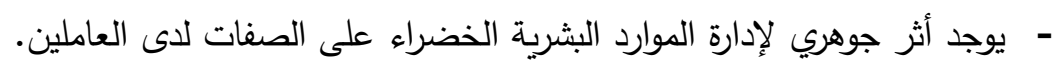
- يوجد أثر جوهري لإدارة الموارد البشرية الخضراء على المعرفة لإى العاملين. - يوجد أثر جوهري لإدارة الموارد البشرية الخضراء على المهارات لدى العاملين.

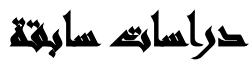

دراسة (Mousa \& Othman, 2020): هدفت إلى تثييم مستوى تتفيذ ممارسات إدارة الموارد البشرية الخضراء في مؤسسات الرعاية الصحية الفلسطينية، وتأثيرها على الأداء

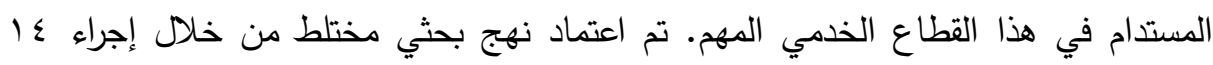

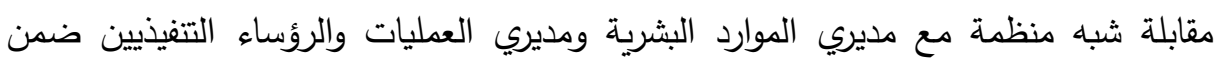
مجموعة من المجالات في قطاع الرعاية الصحية في الضفة الغربية. تم استخدام الدراسة مائة الاستقصائية كأداة كمية لجمع البيانات من 97 مشاركا يستخدمون ممارسات إدارة الموارد البشرية الخضراء على مستويات إدارية مختلفة.

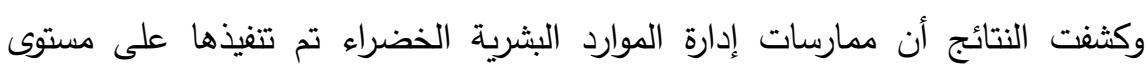
متوسط، وتم تحقيق أداء مستدام على مستوى عالٍ، حيث كانت الممارسات الأكثر تأثيرا هي "التوظيف الأخضر" و "التدريب والمشاركة الخضراء" ؛ كانت الممارسة الخضراء الأقل تأثيرا هي "إدارة الأداء الأخضر والتعويضات". 
دراسة (مناف أحمد, 19 ـ ب): هدفت إلى التعرف على أثر ممارسات أدارة الموارد البشرية الخضراء والمتمثلة بـ (بالتوصيف والتوظيف والتدريب والمكافأة الخضراء) في تحسين أداء المنظمة. حيث تكمن مشكلة الدراسة في ضعف الممارسات الخضراء في المؤسسات والمنظمات العاملة في العراق، وقد اتخذت من المستثفيات العاملة في مركز محافظة الأنبار كعينة للدراسة حيث تم استخدام الأساليب الإحصائية المناسبة وذلك من خلال بناء استبيان وتم توزيعه على عينة المجتمع والبالغ (rA) مفردة. وتوصلت الدراسة لمجموعة من النتائج

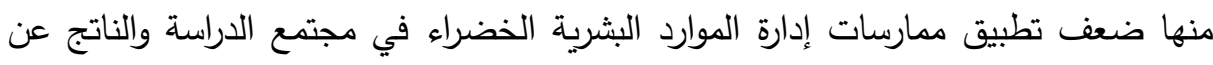
ضعف الوعي بأهمية هذه الممارسات وطرق تطبيقها. دراسة: (Masri, 2016): هدفت الدراسة إلى مساعدة المؤسسات على تحسين الأداء البيئي

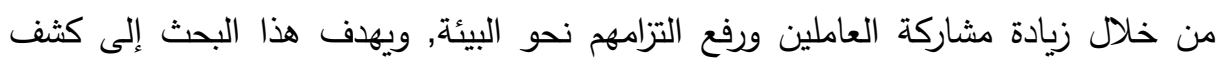

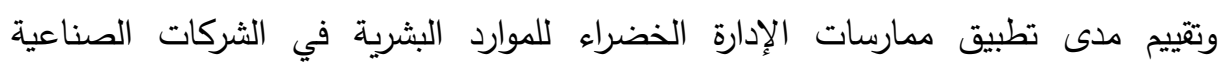
الفلسطينية من ثلاث قطاعات صناعية (الصناعات الغذائية والدوائية والكيميائية) في الضفئة الضئية الغربية. وتم استخدام المنهج الاستكثافي والتحليلي الوصفي المكون من المقابلات والاستبيان

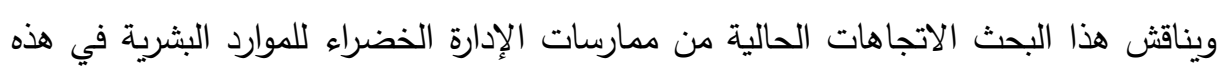

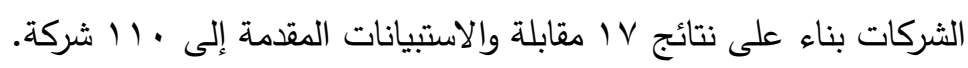

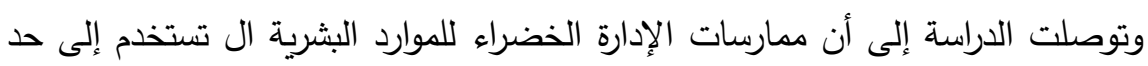

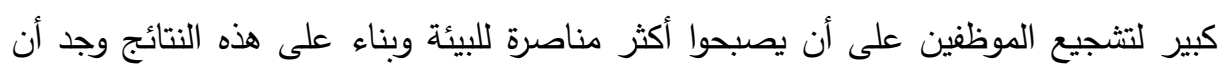

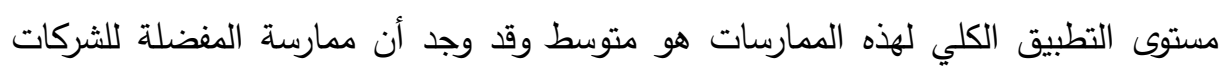
المستهدفة التي زادت التزام الموظفين ورفعت وعيهم تجاه البيئة هي (الإدارة الخضراء , التقافة

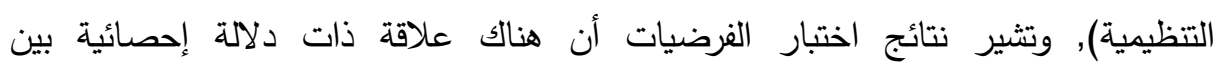
الممارسات إدارة الموارد البشرية الخضراء والأداء البيئي, و أن النظام المحرك الرئيسي لإداد الثارة الموارد البشرية الخضراء هو الاعتبارات الفردية. 
دراسة (محمد عبد الرحمن, • · · P): هدفت إلى تحليل دور مدخل الجدارات بما يتضمنه من

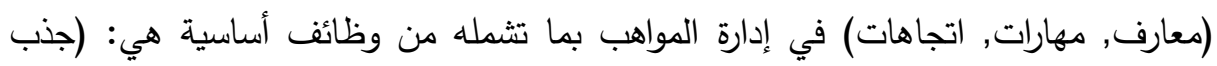
المواهب, تدريب المواهب, واستبقاء المواهب), بالتطبيق على قطاع البنوك التجارية الدصرية,

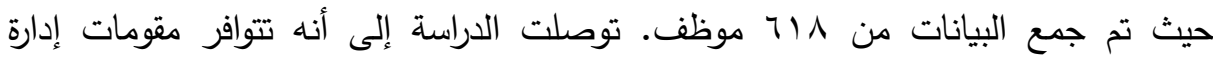
المواهب القائمة على الجدارات في البنوك التجارية بمصر , وتوجد علاقة معنوية بين مكونات

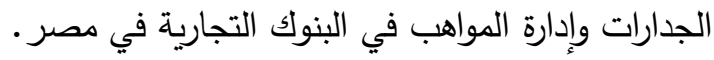

دراسة (Safavi, \& Bouzari, 2019): وهدفت إلى بحث العلاقة بين رأس المال النفسي

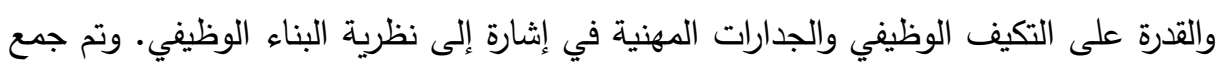
البيانات من بو 19 موظف الخطوط الأمامية في فنادق الخمس نجوم في شمال قبرص.

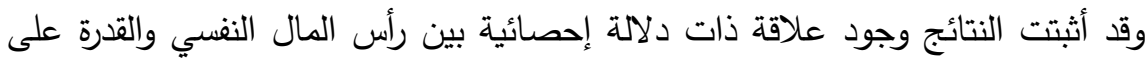

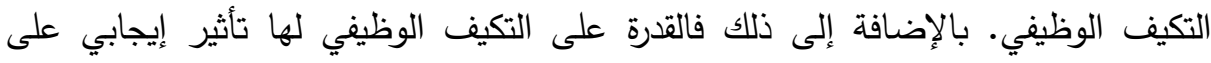

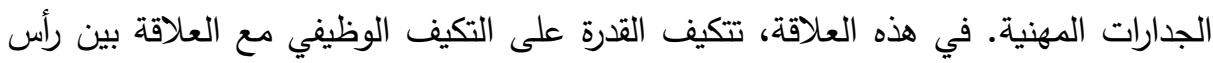
المال النفسي والجدارات المهنية.

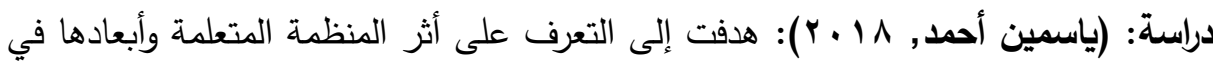

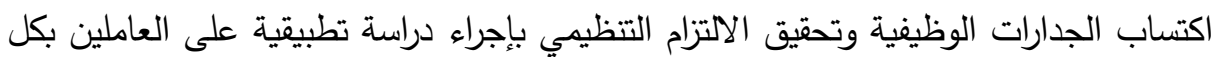

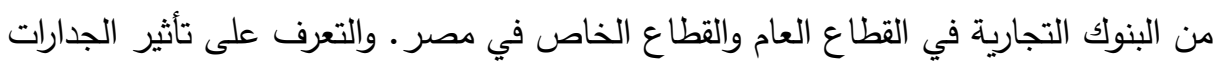

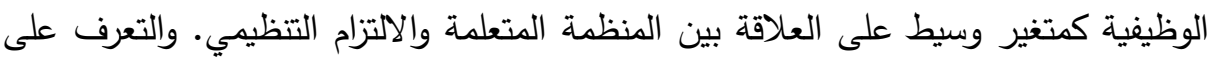

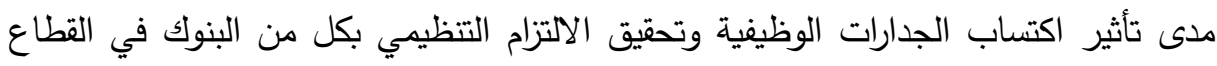
العام والقطاع الخاص. - ماص.

وتوصلت الدراسة إلى وجود تأثير معنوي ذو دلالة إحصائية بين أبعاد المنظمة المتعلمة

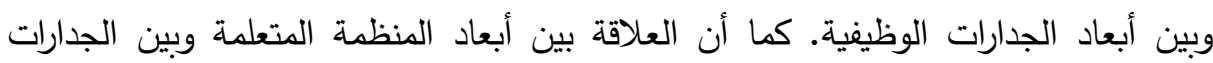
الوظيفية علاقة طردية قوية. كما تبين وجود تأثير معنوي ذو دلالة إحصائية بين أبعاد إداد إنين 
المنظمة المتعلمة وبين أبعاد الالتزام التتظيمي. كما أن العلاقة بين أبعاد المنظمة المتعلمة وبين الالتزام التتظيمي علاقة طردية قوية. من خلال الاستعراض للدراسات السابقة، يتضح أنها تتثابه مع الدراسة الحالية في تتاول موضوع إدارة الموارد البشرية الخضراء وجدارات العاملين في المنظمات وقطاعات الأعمال المختلفة. وقد أكدت معظم الدراسات السابقة على أهمية العمل على فاعلية وكفاءة إدارة الموارد البشرية الخضراء وجدارات العاملين بمنظمات الأعمال.

\section{الإطار اللنظيه}

المتغير المستقل: إدارة الموارد البثرية الخضراء.

يمكن تعريف إدارة الموارد البشرية الخضراء بأنها: دمج كلا من عناصر الموارد البشرية بالقواعد الأساسية للعامل الأخضر من خلال التنظيم والتخطيط والتوجيه والرقابة، وذلك من

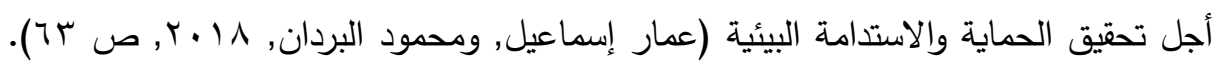
وتم قياس متغير إدارة الموارد البشرية الخضراء من خلال الأبعاد التالية (محمد عرنوس.

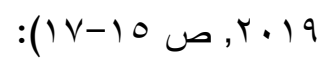

• التوظيف الأخضر : توظيف المواهب الجديدة الذين هم على بينة من نظام البيئة الذي من شأنها أن تدعم الإدارة البيئية الفعالة داخل المنظمة.

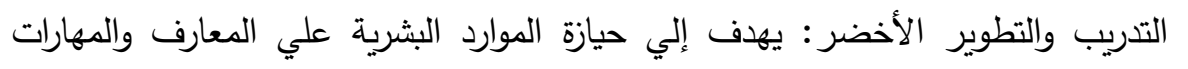
المؤثرة في سلوكهم الأخضر الأمر الذي يتطلب توفير التدريب في المجال البيئي بهدف تتمية الوعي البيئي لديهم. • تقييم الأداء الأخضر : يعبر عن كيفية وضع معايير ومؤشرات لقياس الأداء البيئي على لئى جميع المستويات والحصول على بيانات مفيدة عن أداء المديرين في الدجالات البيئية. 
المتفير التابع: جدارات العاملين.

الجدارة هي الاعتماد الفعال للمعارف والمهارات, من أجل إنجاز معين, وتكون نتيجة

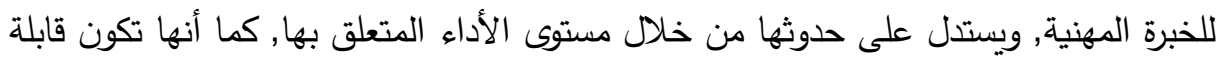

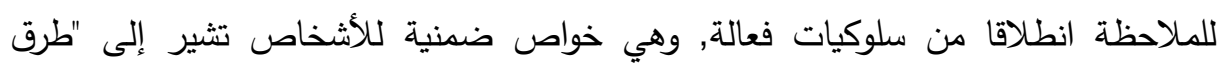

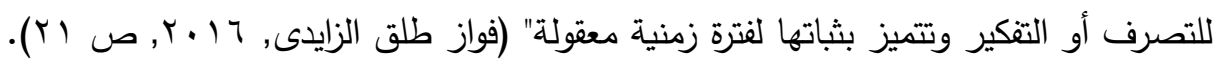

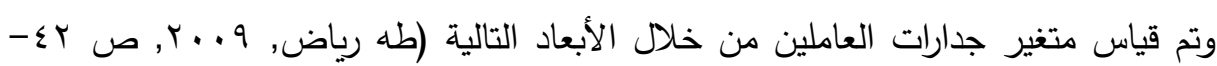

الدوافع: هي الأشياء التي يفكر الفرد أو يرغب فيها باستمرار التي تتسبب في إقدامه على

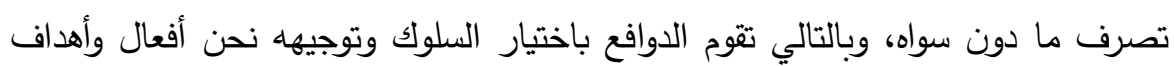

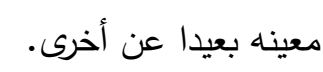

• الصفات: الخصائص المادية والاستجابة المتسقة للظروف أو المعلومات مثال: زمن الاستجابة ودقه الإبصار يعتبران أهم صفات الطيار المقاتل، كما أن التحكم الذاتي في

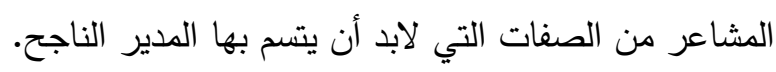

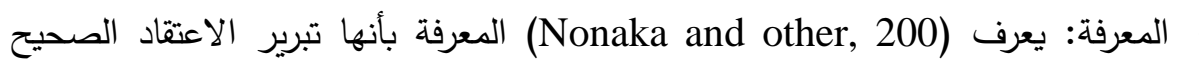

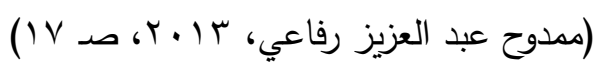

• المهارة: هي القدرة علي أداء مهمة ذهنية أو مادية ومعالجة المعلومات والبيانات وتحديد السبب والنتيجة وتتظيم البيانات والتخطيط والتعرف علي الانماط في بيانات معقدة (لايل سبنسر ، وسيجان سبنسر ، صد و ro ). 


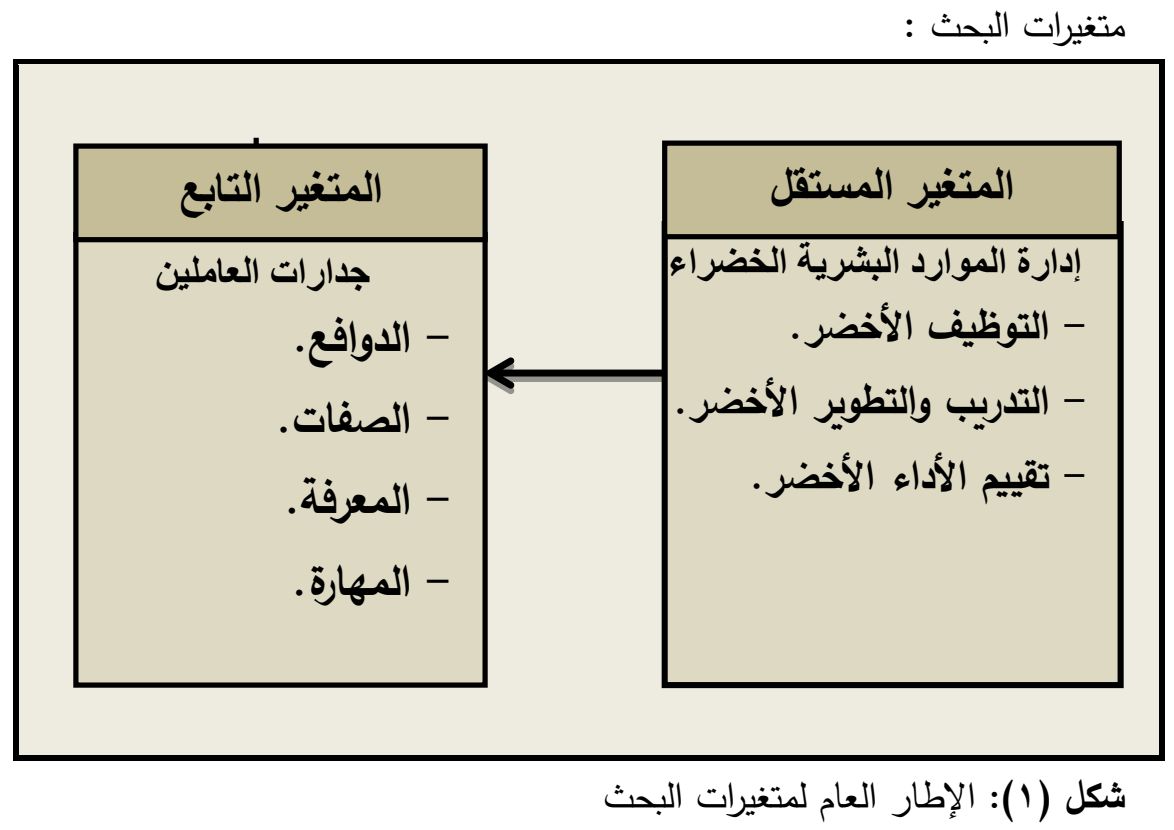

\section{هنهمج المهيد}

انطلاقا من طبيعة موضوع البحث والمعلومات المراد الحصول عليها للكثف عن أثر إدارة الموارد البشرية الخضراء على جدارات العاملين، ومن خلال الأسئلة التي تسعى الدراسة الإجابة عليها، فقد تم الاعتماد في هذه الدراسة على المنهج الوصفي التحليلي. وتم الاعتماد في تحقيق ذلك نوعيين من البيانات من مصادرها التالية: البيانات الثانوية: وهي البيانات التي تم الحصول عليها لبناء الإطار النظري من الكتب منب دابت والمقالات والدراسات السابقة العربية والأجنبية والتي تتاولت موضوعات إدارة الموارد البشرية الخضراء وجدارات العاملين. 
البيانات الأولية: وهي البيانات التي تم جمعها ميدانيا من خلال قائمة الاستقصاء في الدراسة الميدانية لاختبار مدى صحة أو خطأ الفروض التي تقوم عليها الدراسة, حيث استهدفت هذه

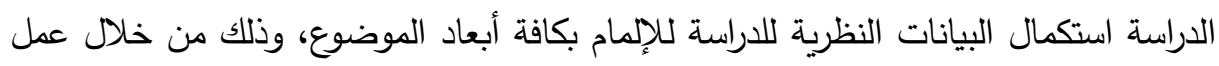
استقصاء ميداني مع العاملين في شركة فودافون محل الدراسة, بثأن الحصول على هذانه

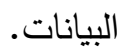

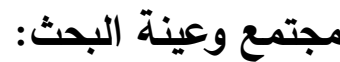

مجتمع الدراسة: يتكون مجتمع الدراسة من العاملين بشركة فودافون في محافظة القاهرة, وعددهم الإجمالي • ع ع فرد, وقت إجراء الدراسة الميدانية. عينة الدراسة: تم اختيار عينة عشوائية بسيطة من مجتمع الدراسة من العاملين, وتم تحديد حجم العينة باستخدام المعادلة التالية: $\mathrm{n}=\frac{\mathrm{NP}(1-\mathrm{P}) \mathrm{x}^{2}}{(\mathrm{~N}-1) \mathrm{d}^{2}+\mathrm{P}(1-\mathrm{P}) \mathrm{x}^{2}}$ حيث أن: n: حجم العينة المطلوبة.

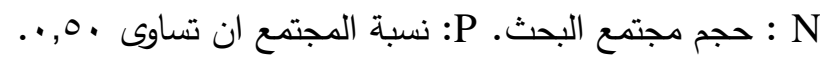

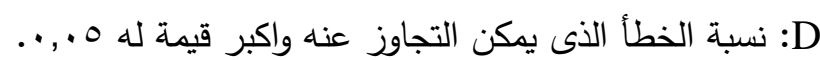

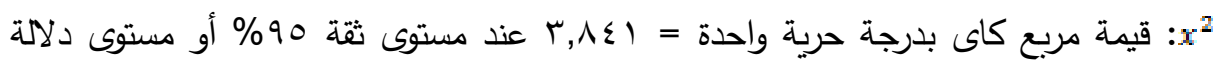
.\%०

وبتطبيق المعادلة السابقة على البيانات المجمعة تم التوصل إلى حجم عينة الدراسة والتي

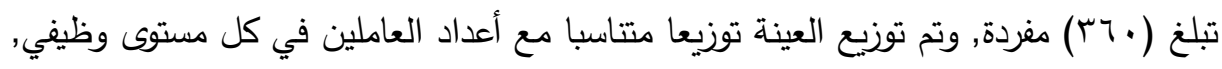

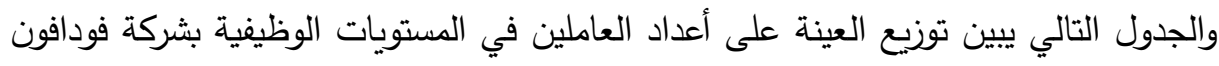
في محافظة القاهرة, كما يلي: 
جدول (1): توزيع العينة على أعداد العاملين في المستويات الوظيفية بشركة فودافون

\begin{tabular}{|c|c|c|c|c|}
\hline الاستجابة & العينة & المجتمع & المستوى & p \\
\hline 5 & 8 & 120 & مدير عام & 1 \\
\hline 35 & 41 & 652 & مدير إدارة & $r$ \\
\hline 49 & 57 & 914 & رئيس قسم & $r$ \\
\hline 211 & 254 & 4054 & موظف & $\varepsilon$ \\
\hline 300 & 360 & 5740 & جمالي & \\
\hline
\end{tabular}

تحليل المتغيرات واختبار الفروض:

أولاً: الوصف العام لأداة البحث: تم استخدام قائمة الاستقصاء كأداة رئيسية للحصول على

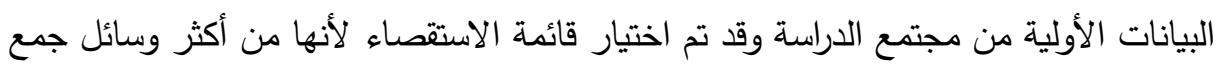
البيانات شيوعا ومواءمتها من الناحية الخاصة بطبيعة الدراسة، وقد تم تصميم قائمة الاستقصاء في ضوء أهداف الدراسة لاختبار فروض الدراسة, والتي تم إعدادها بناء على ولى لئه مراجعة الدراسات السابقة والأبحاث العلمية المتخصصة في الموضوع. وتتضدن قائمة لروضة الاستقصاء المحاور التالية:

المحور الأول: إدارة الموارد البشرية الخضراء: يتضمن التعرف على واقع إدارة الموارد البشرية

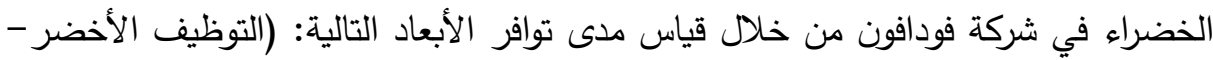

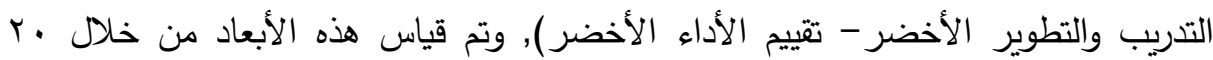
عبارة. وتم الاعتماد في بناء هذا المحور على دراسة: (Mousa, \& Othman, 2020),

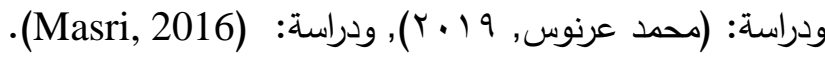
المحور الثاني: جدارات العاملين: يتضمن التعرف على واقع جدارات العاملين في شركة

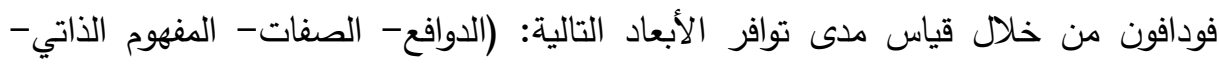

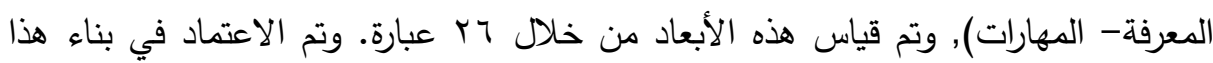

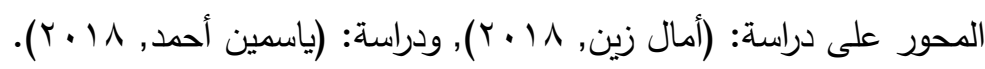


المحور الثالث: المتغيرات الثخصية والوظيفية: يتضمن هذا المحور التعرف على المتغيرات الثخصية والوظيفية المتمثلة في: (النوع, مستوى التعليم, المستوى الوظيفي, سنوات الخبرة) لعينة الدراسة من العاملين في شركة فودافون محل الدراسة. ثانيا: ثبات أداة البحث:

تم إيجاد معامل ارتباط (بيرسون) بين معدل الأسئلة الفردية الرتبة, ومعدل الأسئلة الزوجية الرتبة لكل محور, وقد تم تصحيح معاملات الارتباط باستخدام معامل ارتباط لإنئه

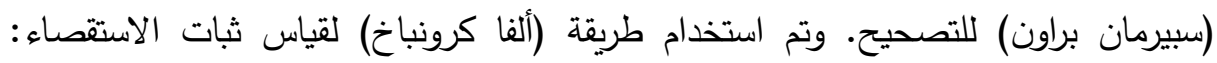
كطريقة ثانية لقياس الثبات.

جدول (r): معامل الثبات (طريقة التجزئة النصفية, وألفا كرونباخ)

\begin{tabular}{|c|c|c|c|c|c|c|}
\hline \multirow[b]{2}{*}{ كرونباخ } & \multicolumn{4}{|c|}{ التجزئة النصفية } & \multirow[b]{2}{*}{ محتوى المحور } & \multirow[b]{2}{*}{ المحور } \\
\hline & المعنوية & الارتباط & الارتباط & الفقرات & & \\
\hline 0.826 & 0.000 & 0.726 & 0.719 & 5 & التوظيف الأخضر & الأول \\
\hline 0.824 & 0.000 & 0.797 & 0.791 & 5 & التدربب والتطوبر الأخضر & الثانى \\
\hline 0.822 & 0.000 & 0.836 & 0.831 & 5 & تقييم الأداء الأخضر & الثالث \\
\hline 0.867 & 0.000 & 0.868 & 0.766 & 15 & 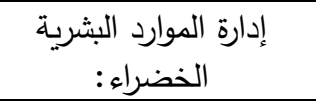 & المستقل \\
\hline 0.842 & 0.000 & 0.892 & 0.888 & 4 & الدوافع & الأول \\
\hline 0.825 & 0.000 & 0.794 & 0.788 & 4 & الصفات & 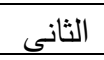 \\
\hline 0.821 & 0.000 & 0.839 & 0.801 & 4 & المعرفة & الثالث \\
\hline 0.817 & 0.000 & 0.843 & 0.838 & 4 & المهارات & الرابع \\
\hline 0.706 & 0.000 & 0.875 & 0.789 & 16 & جدارات العاملين & التابع \\
\hline 0.897 & 0.000 & 0.798 & 0.741 & 31 & جميع الفقرات & \\
\hline
\end{tabular}


يبين الجدول السابق أن هناك معامل ثبات كبير نسبيا لفقرات الاستقصاء, حيث أن

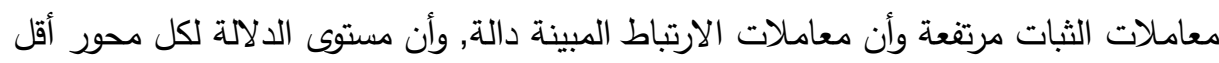

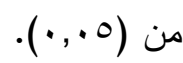

التحليل الوصفي لمتغيرات البحث: تم تحليل البيانات باستخدام الوسط الحسابي لمعرفة متوسط الآراء ومدى الموافقة على العبارات التي تشتملها قائمة الدراسة الميدانية, كما يأتي:

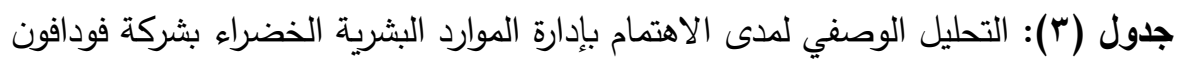

\begin{tabular}{|c|c|c|c|c|c|c|}
\hline الترتيب & التوافر & النسبي \% الوزن & الانعراف & الوسطابي & العناصر & 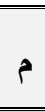 \\
\hline 1 & مرتنعة & 82.4 & 0.709 & 4.12 & تتبنى الشركة مبادرات حماية & 1 \\
\hline 4 & متوسطة & 57.8 & 0.987 & 2.98 & الوعتى الأخضر موارد بشاه البيئة لديهُ & $r$ \\
\hline 2 & 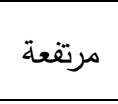 & 68.8 & 1.012 & 3.44 & القرارات الخضراء العاملين في اتخاذة للبيئة. & r \\
\hline 3 & 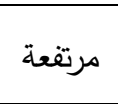 & 64.4 & 0.957 & 3.22 & صيقوم الموظفون بمعارسات ألبئة العمل. & $\varepsilon$ \\
\hline 5 & متوسطة & 58.0 & 1.022 & 2.90 & يحرص الكوظة الكوبنية أثناء العلى ترشيد. & 0 \\
\hline الأول & مرتفعة & 66.6 & 0.937 & 3.33 & التوظيف الأخضر & \\
\hline 1 & مرتفعة & 77.0 & 0.772 & 3.85 & التدريب المستمر للعاملين لرفع البئي لديهم. & 1 \\
\hline 3 & 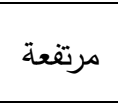 & 65.2 & 0.809 & 3.26 & المتطدوام أحدث الأساليب. & $r$ \\
\hline 2 & مرتفعة & 66.2 & 1.020 & 3.31 & 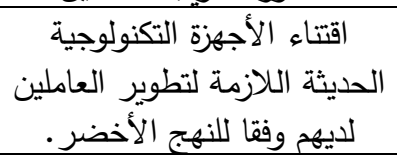 & r \\
\hline 4 & مرتفعة & 60.0 & 0.843 & 3.00 & 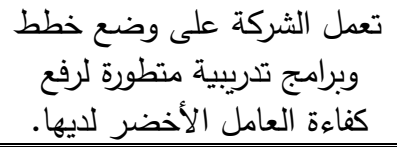 & $\varepsilon$ \\
\hline
\end{tabular}


مجلة العلوم البيئية

معهد الدراسات والبحوث البيئية - جامعة عين شمس لبنه

أحمد محمد عبد المنعم وآخرون

\begin{tabular}{|c|c|c|c|c|c|c|}
\hline الترتيب & التوافر & النسبي \% الون & المعياري & الوسابي & العناصر & م \\
\hline 5 & متوسطة & 57.0 & 0.812 & 2.85 & أشارك بكل الدورات التدريبية & 0 \\
\hline الثانى & مرتفعة & 65.0 & 0.851 & 3.25 & التدربب والتطوبر الأخضر & \\
\hline 1 & 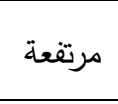 & 73.6 & 0.857 & 3.68 & تتفيذ وإتباع النهاءج الأخضر أثناء أليومية. & 1 \\
\hline 3 & 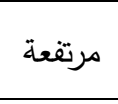 & 63.4 & 0.881 & 3.17 & 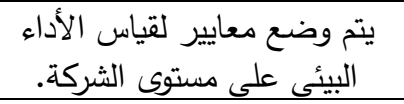 & $r$ \\
\hline 5 & متوسطة & 54.0 & 0.745 & 2.70 & 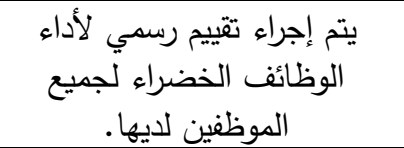 & r \\
\hline 2 & مرتفعة مر & 65.4 & 1.017 & 3.27 & تقدم الثركة ملاحظات للموظفين & $\varepsilon$ \\
\hline 4 & 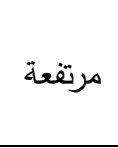 & 61.2 & 0.809 & 3.06 & تشكار الحل الشركة تقديم العاملين & 0 \\
\hline \multirow[t]{2}{*}{ الثالث } & مرتفعة & 63.4 & 0.729 & 3.17 & تقييم الأداء الأخضر & \\
\hline & مرتفعة & 65.0 & 0.839 & 3.25 & إدارة الموارد البشربة الخضراء: & \\
\hline
\end{tabular}

يتبين من نتائج الجدول السابق أن الاهتمام بإدارة الموارد البشرية الخضراء بشركة فودافون محل الدراسة بصفة عامة بحسب استجابات عينة الدراسة كان بدرجة مرتفعة, وأن الآراء تتجه نحو الموافقة اتجاه عبارات الدراسة الميدانية الخاصة بإدارة الموارد البشرية

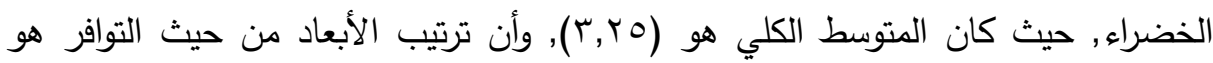

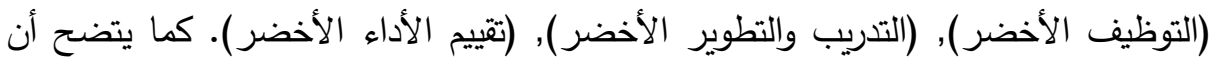

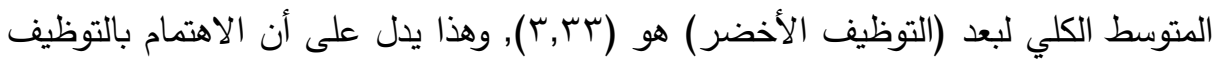

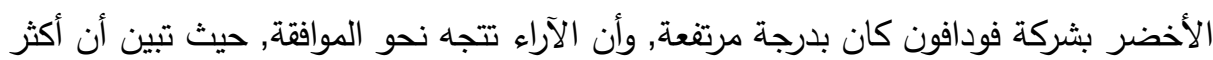

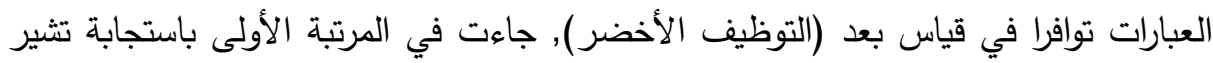


إلى الموافقة التامة عبارة رقم: ( ) بمتوسط قدره (Yr, ؟), وأن أقل العبارات توافرا جاءت في

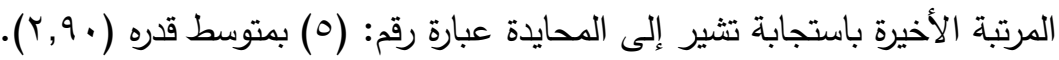

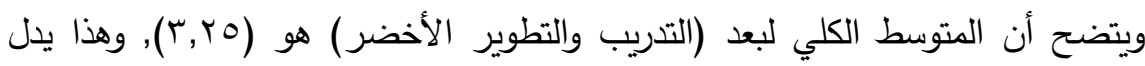
على أن الاهتمام بالتدريب والتطوير الأخضر كان بدرجة مرتفعة بشركة فودافون, وأن الآراء

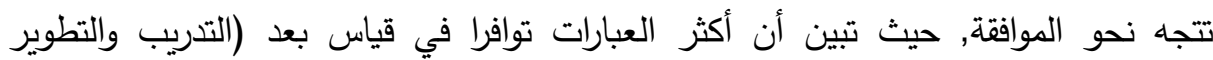

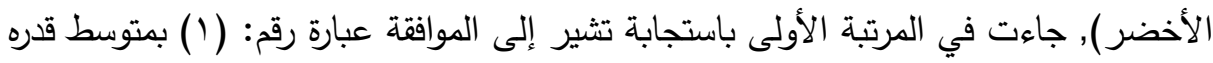

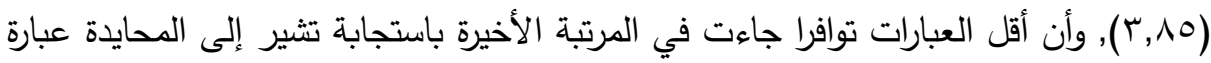

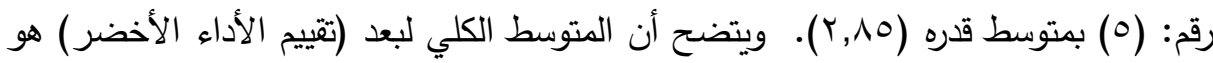

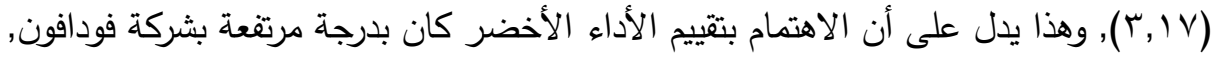

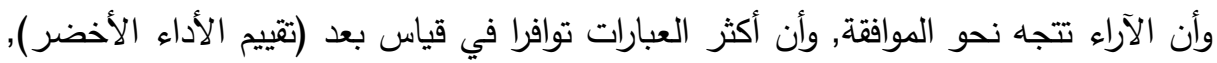

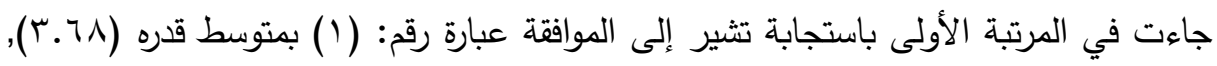

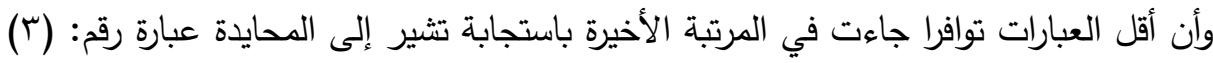

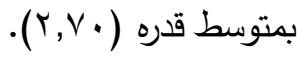


مجلة العلوم البيئية

معهد الدراسات والبحوث البيئية - جامعة عين شمس البية

أحمد محمد عبد المنعم وآخرون

جدول (؟): التحليل الوصفي لمدى جدارات العاملين بشركة فودافون

\begin{tabular}{|c|c|c|c|c|c|c|}
\hline الترتيب & الموافقة & النسبي\% & المعياري & الحسابي & العناصر & م \\
\hline 4 & متوسطة & 55.8 & 0.741 & 2.79 & تراعى الثركة دوافع العاملين بها. & 1 \\
\hline 3 & 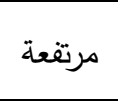 & 62.8 & 0.976 & 3.14 & تحرص الشركة على رفع مستوى & r \\
\hline 2 & 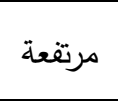 & 71.0 & 0.757 & 3.55 & لدى القدرة على التوصل إلى أفكار & r \\
\hline 1 & 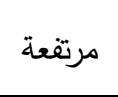 & 71.6 & 0.824 & 3.58 & 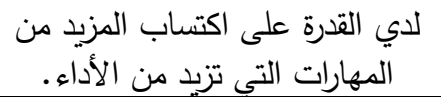 & $\varepsilon$ \\
\hline 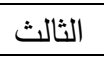 & مرتفعة & 65.6 & 0.814 & 3.28 & الدوافع & \\
\hline 3 & 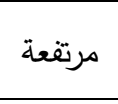 & 64.2 & 0.746 & 3.21 & أتتع بالقدرة على اكتثاف & 1 \\
\hline 4 & 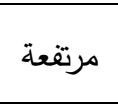 & 63.4 & 0.725 & 3.17 & أستطيع استتباط الحلول حول. & r \\
\hline 2 & 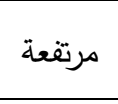 & 66.8 & 0.928 & 3.34 & تلتوفر للى المقدرة على تقييم & $r$ \\
\hline 1 & مرتفعة - مرت & 69.0 & 0.884 & 3.45 & للى القابلية للاستفادة من الأخطاء. & $\varepsilon$ \\
\hline 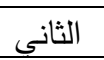 & مرتفعة & 65.8 & 0.820 & 3.29 & الصفات & \\
\hline 1 & مرتفعة & 80.0 & 1.021 & 4.00 & أقوم بتمية مهاراتي المعرفية & 1 \\
\hline 2 & مرتفعة & 69.8 & 1.016 & 3.49 & لدي القدرة على الاطلاع الدائم لحل & $r$ \\
\hline 4 & متوسطة & 58.4 & 0.847 & 2.92 & أقوم بحضور الندوات الثقافية التي & $r$ \\
\hline 3 & مرتفعة & 62.4 & 0.937 & 3.12 & لدى القدرة على ربط الأحداث & $\varepsilon$ \\
\hline
\end{tabular}


مجلة العلوم البيئية

معهد الدراسات والبحوث البيئية - جامعة عين شمس البية

أحمد محمد عبد المنعم وآخرون

تابع جدول (؛ ): التحليل الوصفي لمدى جدارات العاملين بشركة فودافون

\begin{tabular}{|c|c|c|c|c|c|c|}
\hline الترتيب & الموافقة & النوني\% & المعياري & الحسابي & العناصر & 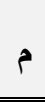 \\
\hline الأول & مرتفعة & 67.6 & 0.955 & 3.38 & \multicolumn{2}{|l|}{ المعرفة } \\
\hline 1 & مرتفعة & 67.4 & 0.947 & 3.37 & أتتع بقدرات العرض الواضح & 1 \\
\hline 4 & مرتفعة & 61.4 & 1.036 & 3.07 & لاى مهارات تحليلية للمواقف & r \\
\hline 3 & مرتفعة & 63.2 & 1.021 & 3.16 & أحرص على تتشيط مهاراتي لحل & $r$ \\
\hline 2 & مرتفعة & 67.0 & 0.835 & 3.35 & لدى القدرة على تخطيط الأعمال. & $\varepsilon$ \\
\hline الرابع & مرتفعة & 64.6 & 0.959 & 3.23 & \multicolumn{2}{|l|}{ المهارات } \\
\hline & مرتفعة & 65.8 & 0.887 & 3.29 & \multicolumn{2}{|l|}{ جدارات العاملين: } \\
\hline
\end{tabular}

يتبين من نتائج الجدول السابق أن توافر جدارات العاملين بشركة فودافون كان بدرجة

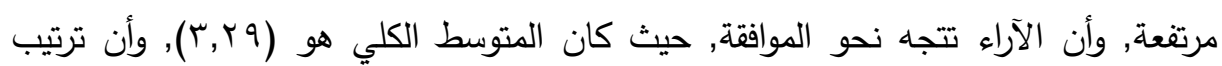

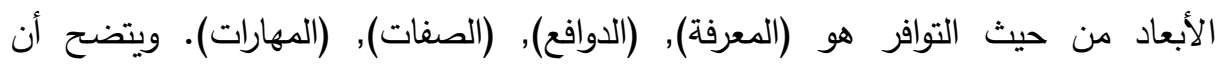

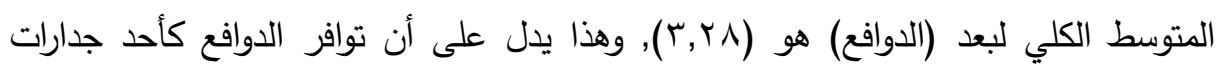

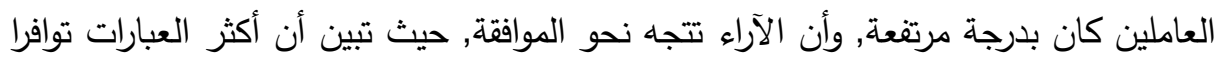

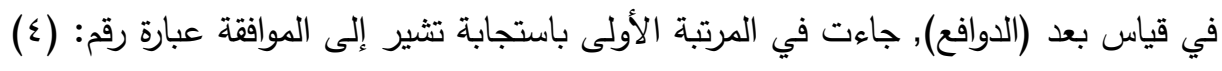

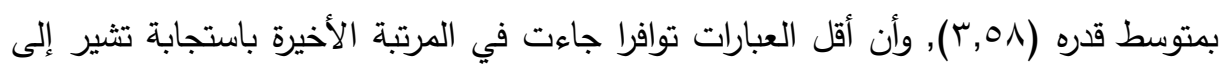

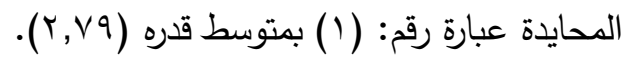

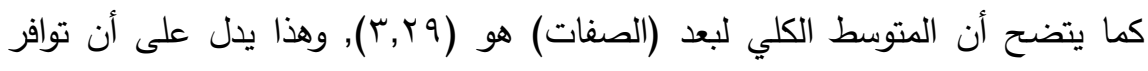

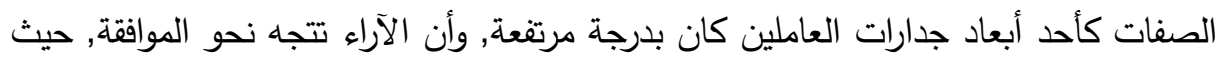

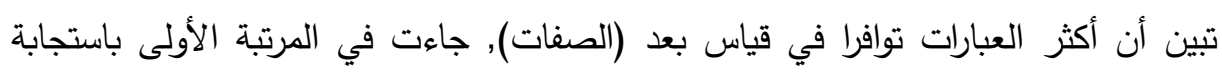

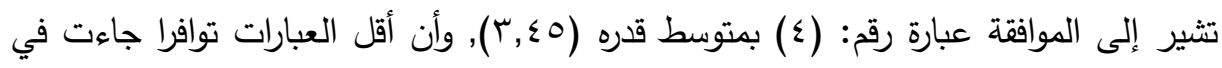

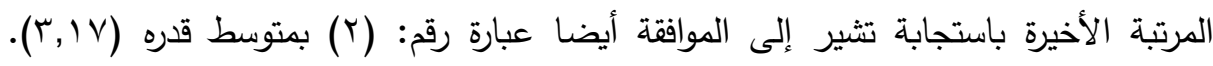


ويتضح أن المتوسط الكلي لبعد (المعرفة) هو (^ی,r), وهذا يدل على أن المعرفة كأحد أبعاد

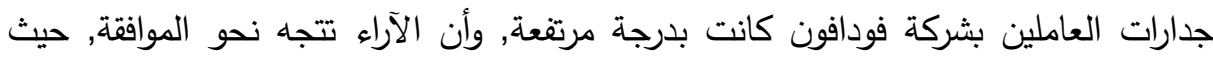

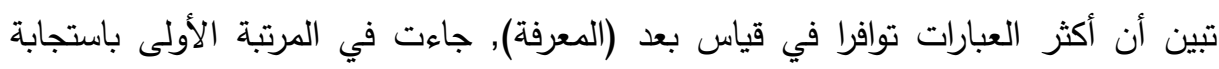

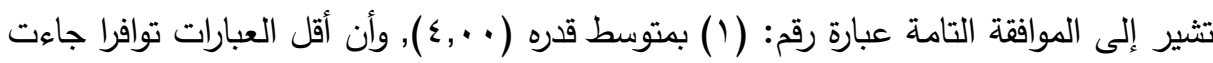

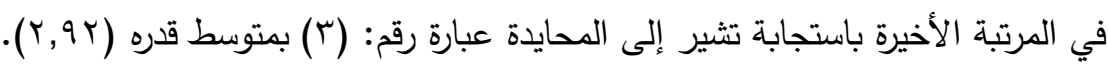

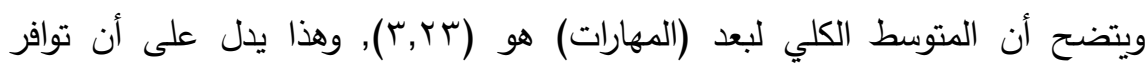
المهارات كأحد أبعاد جدارات العاملين كانت بدرجة مرتفعة, وأن الآراء تتجه نحو الموافقة, وأن

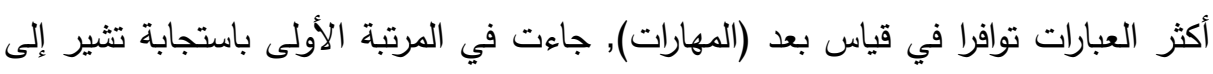

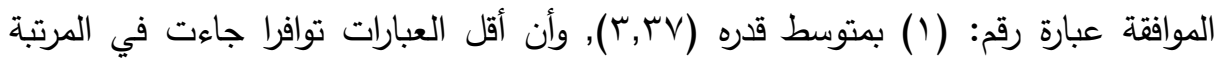

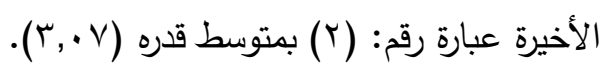

اختبار الفروض: ينص الفرض الرئيسي على أنه: " يوجد أثر جوهري لإدارة الموارد البشرية

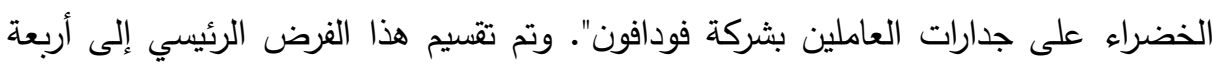
فروض فرعية، وتم إجراء بعض الاختبارات وذلك من أجل ضمان ملاءمة البيانات لافتراضات

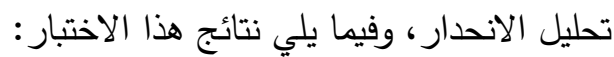
جدول (ه): نتائج اختبار التطابق بين أبعاد المتغير المستقل (إدارة الموارد البشرية الخضراء)

\begin{tabular}{|c|c|c|c|c|}
\hline $\begin{array}{l}\text { معامل الالتواء } \\
\text { Skewness }\end{array}$ & $\begin{array}{c}\text { التباين المسموح به } \\
\text { Tolerance }\end{array}$ & التباين (VIF) & إدارة الموارد البشرية & م \\
\hline 0.641 & 0.615 & 5.311 & التوظيف الأخضر & 1 \\
\hline 0.593 & 0.537 & 6.812 & التدريب والتطوير & r \\
\hline 0.624 & 0.581 & 7.307 & تقييم الأداء الأخضر & $r$ \\
\hline
\end{tabular}

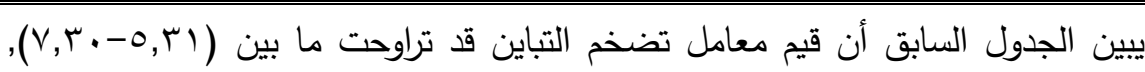
وتعتبر هذه القيم مناسبة وتثير إلى عدم وجود مشكلة ارتباط خطي بين أبعاد المتغير المستقل فئل

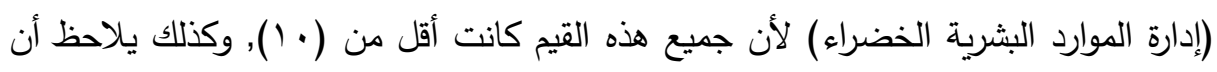

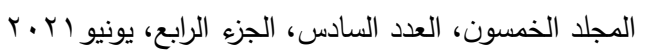

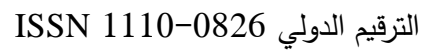


قيم التباين المسموح به قد تراوحت ما بين (سه,.•--17, •) وجميع هذه القيم تعتبر أكبر من (0., •), مما يساعد في الاستتاج بعدم وجود مشكلة الارتباط الخطي المتعدد بين أبعاد

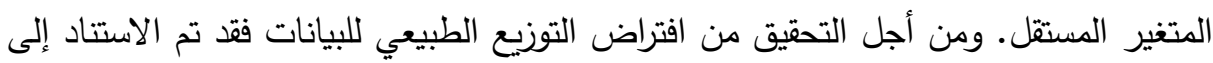

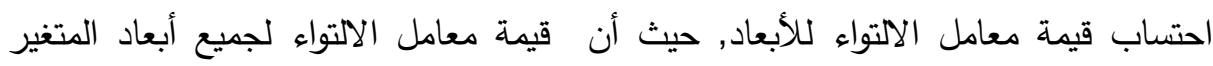

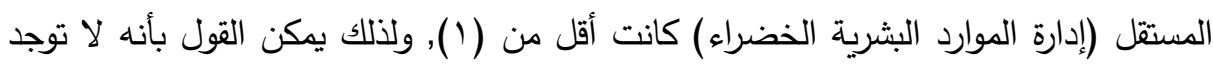
مشكلة حقيقية تتعلق بالتوزيع الطبيعي لبيانات الدراسة.

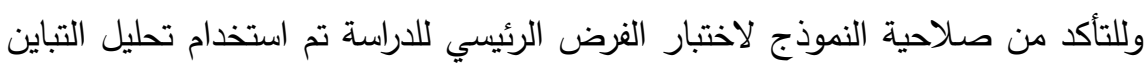
للانحدار من خلال اختبار (F) كما يلي: جدول (†): نتائج تحليل التباين للانحدار للتأكد من صلاحية النموذج للاختبار

\begin{tabular}{|c|c|c|c|c|c|}
\hline مستوى المعنوية & المحسوبة F & $\begin{array}{c}\text { معامل التحديد } \\
\text { R }^{2}\end{array}$ & الحرجة & المتغير التابع & م \\
\hline 0.011 & $* 321.27$ & 0.527 & 297 & الدوافع & 1 \\
\hline 0.000 & $* 256.62$ & 0.720 & 297 & الصفات & $r$ \\
\hline 0.000 & $* 238.18$ & 0.710 & 297 & المعرفة & $r$ \\
\hline 0.007 & $* 227.57$ & 0.570 & 297 & المهارات & $\varepsilon$ \\
\hline 0.000 & $* 271.52$ & 0.609 & 297 & \multicolumn{2}{|c|}{ جدارات العاملين } \\
\hline
\end{tabular}

الدلالة الإحصائية عند مستوى المعنوية (0. . •).

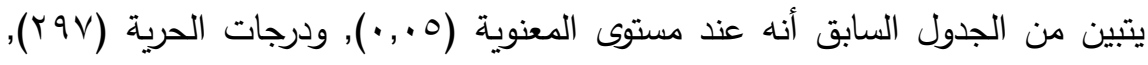

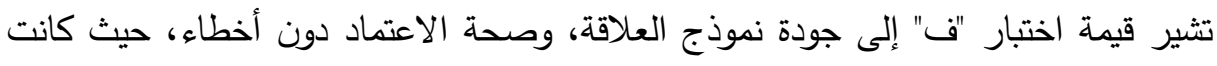

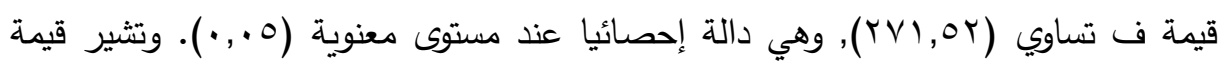

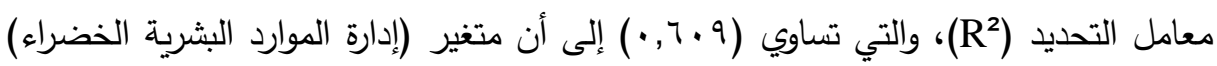
يفسر التغيير في (جدارات العاملين) بنسبة (9, • ؟7\%) تقريبا، وتتبقي نسبة الأخطاء العشوائية

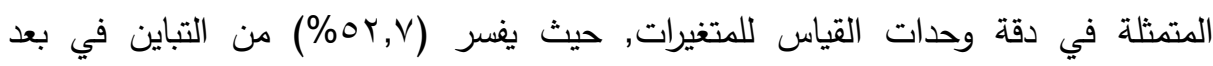

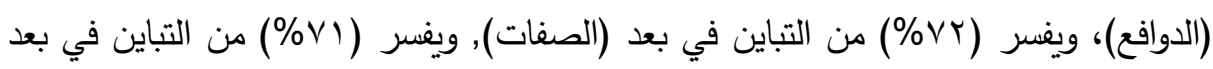

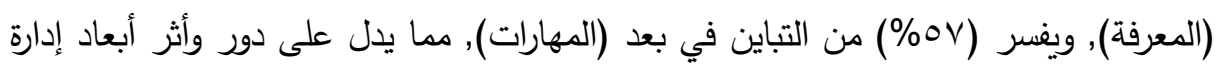
384 
الموارد البشرية الخضراء في تفسير الأبعاد التابعة لمتغير جدارات العاملين. مما يؤكد صلاحية

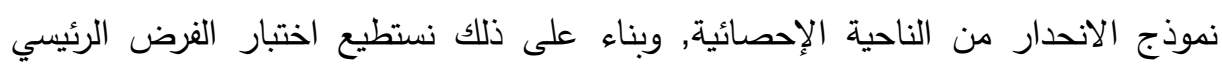

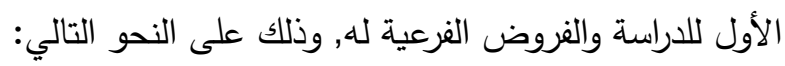
اختبار الفرض الفرعي الأول: والذي ينص على أنه: "يوجد أثر جوهري لإدارة الموارد البشرية الخضراء على الدوافع بشركة فودافون".

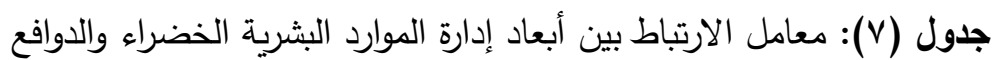

\begin{tabular}{|c|c|c|c|}
\hline \multicolumn{2}{|c|}{ الدوافع } & إدارة الموارد البشرية الخضراء & 5 \\
\hline ارتباط موجب قوي & $0.736 * *$ & التوظيف الأخضر & 1 \\
\hline ارتباط موجب متوسط & $0.667 * *$ & التدربب والتطوير الأخضر & $r$ \\
\hline ارتباط موجب قوي & $0.712 * *$ & تقييم الأداء الأخضر & $r$ \\
\hline ارتباط موجب قوي & $0.726 * *$ & الارتباط الكلي & \\
\hline
\end{tabular}

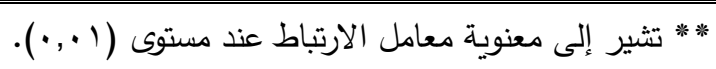

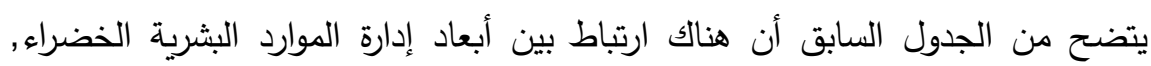

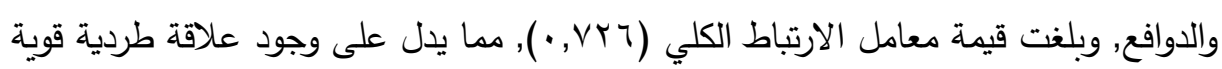
عند مستوى المعنوية (1 •., ). جدول (^): نتائج تحليل الانحدار المتعدد لاختبار أثر إدارة الموارد البشرية الخضراء على ) لـ

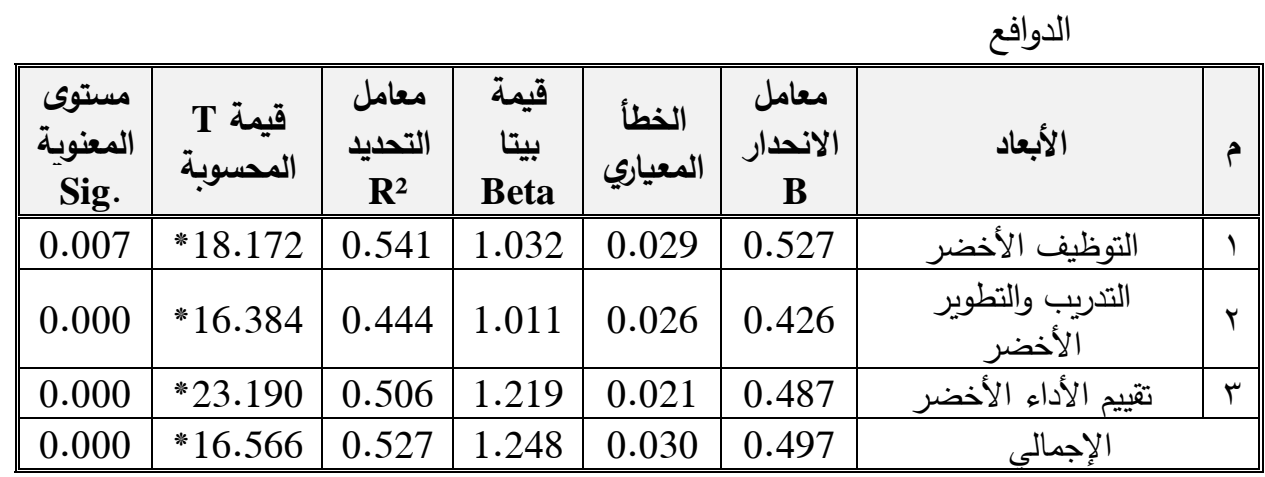
الدلالة الإحصائية عند مستوى المعنوية (0. • ). 
من الجدول السابق ومن متابعة قيم اختبار (t) تبين أن الدلالة الإحصائية أقل من

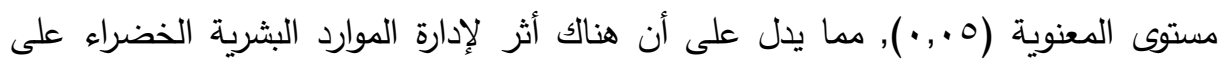

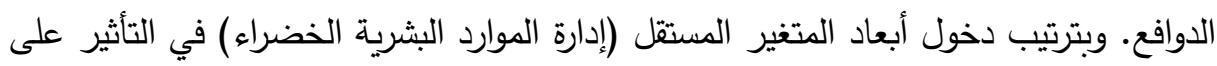

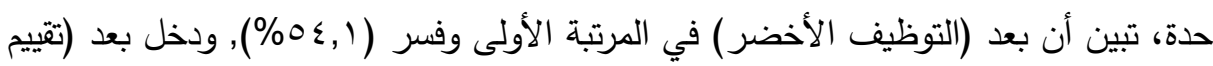
الأداء الأخضر) في المرتبة الثانية وفسر (7, •0\%), ودخل بعد (التدريب والتطوير الأخضر ) في المرتبة الثالثة وفسر (§,؟ء٪), ومعظمها نسب متوسطة لتفسير التباين في البعد التابع

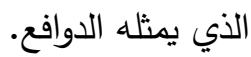

وبناء عليه يمكن قبول الفرض, حيث أن: هناك علاقة ارتباط طردية وأثر ذو دلالة إحصائية بين إدارة الموارد البشرية الخضراء والدوافع لدى العاملين. اختبار الفرض الفرعي الثاني: والذي ينص على أنه: " يوجد أثر جوهري لإدارة الموارد البشرية الخضراء على الصفات لدى العاملين".

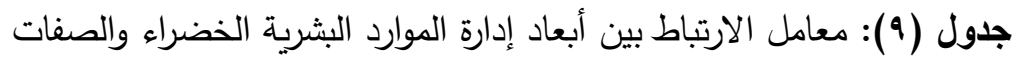

\begin{tabular}{|c|c|c|c|}
\hline \multicolumn{2}{|c|}{ الصفات } & إدارة الموارد البشرية الخضراء & 5 \\
\hline ارتباط موجب قوي & $0.794 * *$ & التوظيف الأخضر & 1 \\
\hline ارتباط موجب قوي & $0.887 * *$ & التدربب والتطوبر الأخضر & r \\
\hline ارتباط موجب قوي & $0.905 * *$ & تقييم الأداء الأخضر & $r$ \\
\hline ارتباط موجب قوي & $0.849 * *$ & الارتباط الكلى & \\
\hline
\end{tabular}

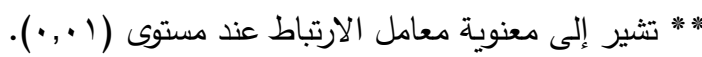

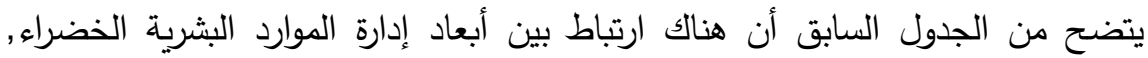
والصفات, وقد بلغت قيمة معامل الارتباط الكلي (9 ^^, •), مما يدل على وجود علاقة طردية قوية عند مستوى المعنوية (1 ( , •). 
مجلة العلوم البيئية

معهد الداسات والبحوث البيئية - جامعة عين شمس لإسية

أحمد محمد عبد المنعم وآخرون

جدول (• (1): نتائج تحليل الانحدار المتعدد لاختبار أثر إدارة الموارد البشرية الخضراء على الصفات

\begin{tabular}{|c|c|c|c|c|c|c|c|}
\hline $\begin{array}{c}\text { المعنوية } \\
\text { Sig. }\end{array}$ & قالمصسوبة T & $\begin{array}{c}\text { معامل } \\
\text { التحديد } \\
\mathbf{R}^{2}\end{array}$ & قيمة بيتا & المعياري & $\begin{array}{c}\text { الانحدار } \\
\text { B } \\
\text { B }\end{array}$ & الأبعاد & b \\
\hline 0.000 & $* 25.791$ & 0.630 & 1.157 & 0.024 & 0.619 & التوظيف الأخضر & 1 \\
\hline 0.000 & $* 30.040$ & 0.786 & 1.287 & 0.025 & 0.751 & التدريب والتطوير & r \\
\hline 0.000 & $* 44.000$ & 0.819 & 1.206 & 0.018 & 0.792 & تقييم الأداء & $r$ \\
\hline 0.000 & $* 24.206$ & 0.720 & 1.249 & 0.029 & 0.702 & الإجمالى & \\
\hline
\end{tabular}

الدلالة الإحصائية عند مستوى المعنوية (0., ·).).

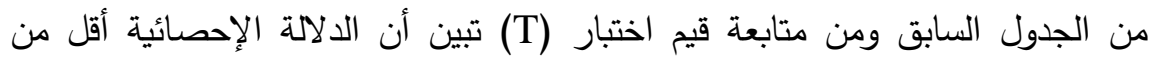

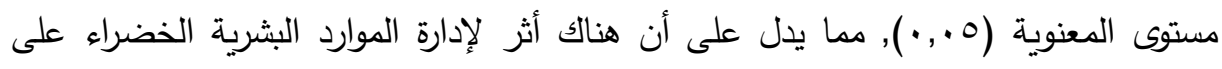

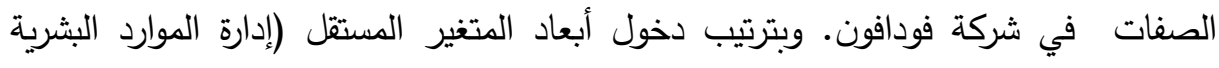

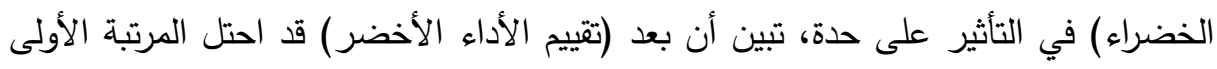

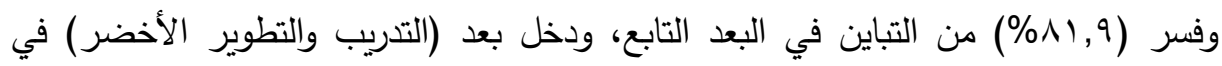

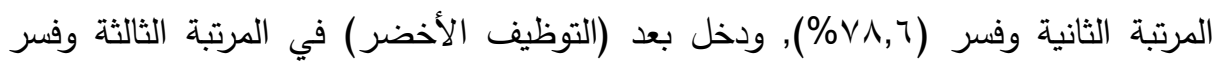
( • , (7\%\%), ومعظمها نسب مرتفعة لتفسير التباين في البعد التابع الذي يمثله الصفات. وبناء عليه يمكن قبول الفرض, حيث أن: هناك علاقة ارتباط طردية وأثر ذو دلالة إحصائية بين إدارة الموارد البشرية الخضراء والصفات كأحد أبعاد جدارات العاملين. اختبار الفرض الفرعي الثالث: والذي ينص على أنه: "يوجد أثر جوهري لإدارة الموارد البشرية الخضراء على المعرفة بشركة فودافون". 
مجلة العلوم البيئية

معهد الدراسات والبحوث البيئية - جامعة عين شمس لبئه

أحمد محمد عبد المنعم وآخرون

جدول (11): معامل الارتباط بين أبعاد إدارة الموارد البشرية الخضراء والمعرفة

\begin{tabular}{|c|c|c|c|}
\hline \multicolumn{2}{|c|}{ المعرفة } & إدارة الموارد البشريـة الخضراء & م \\
\hline ارتباط موجب قوي & $0.712 * *$ & التوظيف الأخضر & 1 \\
\hline ارتباط موجب متوسط & $0.668 * *$ & التدربب والتطوبر الأخضر & r \\
\hline ارتباط موجب قوي & $0.751 * *$ & تقييم الأداء الأخضر & $r$ \\
\hline ارتباط موجب قوي & $0.843 * *$ & الارتباط الكلي & \\
\hline
\end{tabular}

** تثير إلى معنوية معامل الارتباط عند مستوى (1 . . •).

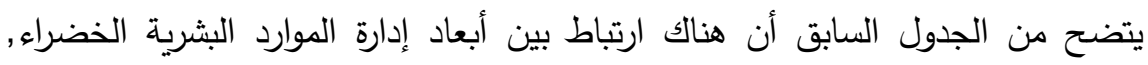

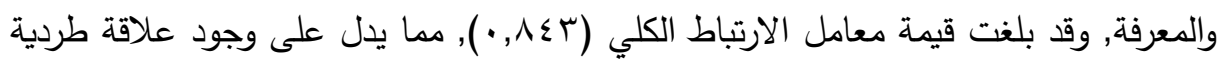

$$
\text { قوية عند مستوى المعنوية (1 •., ). }
$$

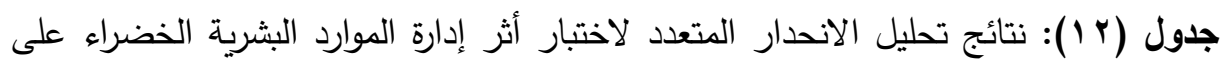
المعرفة - (الم

\begin{tabular}{|c|c|c|c|c|c|c|c|}
\hline المعنوية. مستوى & قالمسيوبة & $\begin{array}{c}\text { التحديدمل } \mathbf{R}^{2} \\
\end{array}$ & قيمة بيتا & الخعياري & معامل & الأبعاد & $p$ \\
\hline 0.000 & $* 17.357$ & 0.506 & 1.347 & 0.028 & 0.486 & الأخضيف & 1 \\
\hline 0.000 & * 17.541 & 0.446 & 1.279 & 0.024 & 0.421 & الأخضر التطريبر & $r$ \\
\hline 0.000 & * 17.633 & 0.564 & 1.208 & 0.030 & 0.529 & تقييم الأداء & $r$ \\
\hline 0.000 & $* 32.952$ & 0.710 & 1.948 & 0.021 & 0.692 & لإجمالى & \\
\hline
\end{tabular}

الدلالة الإحصائية عند مستوى المعنوية (0., .).

باستعراض النتائج الواردة في الجدول السابق ومن متابعة قيم اختبار (T) تبين أن الدلالة الإحصائية أقل من مستوى المعنوية (0., •), مما يدل على أن هناك أثر لإلى إدارة الموارد

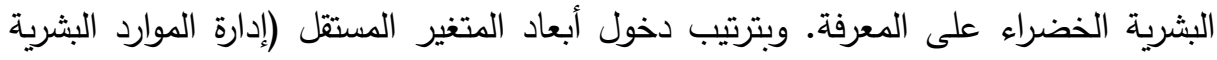

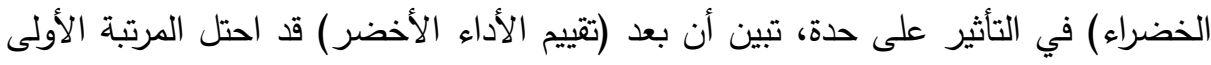
388 
وفسر (7,0\%) من التباين في البعد التابع، ودخل بعد (التوظيف الأخضر) في المرتبة

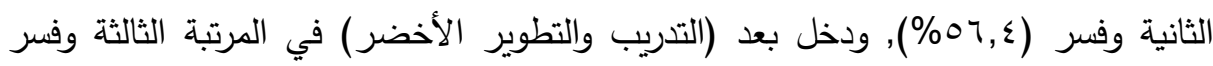

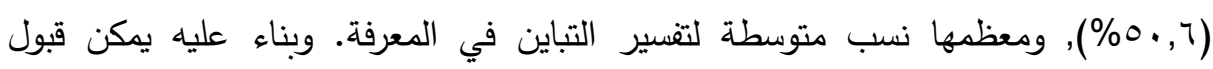
الفرض, حيث أن: هناك علاقة ارتباط طردية وأثر ذو دلالة إحصائية بين إدارة الموارد البشرية الخضراء والمعرفة كأحد أبعاد جدارات العاملين.

اختبار الفرض الفرعي الرابع: والذي ينص على أنه: "يوجد أثر جوهري لإدارة الموارد البشرية الخضراء على المهارات بشركة فودافون".

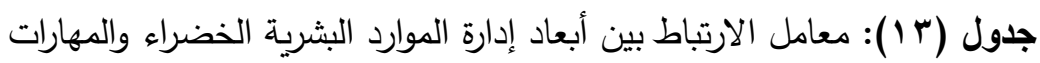

\begin{tabular}{|c|c|c|c|}
\hline \multicolumn{2}{|c|}{ المهارات } & إدارة الموارد البشرية الخضراء & r \\
\hline ارتباط موجب قوي & $0.802 * *$ & التوظيف الأخضر & 1 \\
\hline ارتباط موجب متوسط & $0.548 * *$ & التدريب والتطوير الأخضر & $r$ \\
\hline ارتباط موجب متوسط & $0.668 * *$ & تقييم الأداء الأخضر & $r$ \\
\hline ارتباط موجب قوي & $0.755 * *$ & الارتباط الكلي & \\
\hline
\end{tabular}

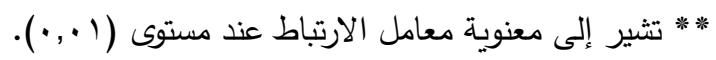

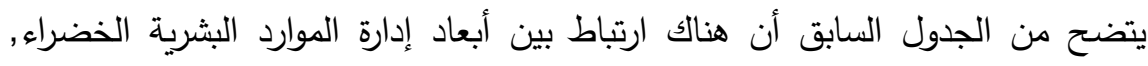

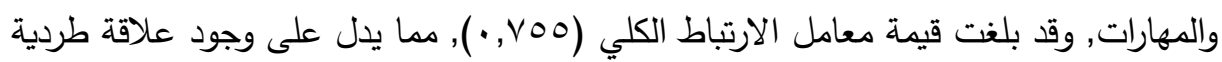
قوية عند مستوى المعنوية (1 •., ). 
جدول (؛ 1): نتائج تحليل الانحدار المتعدد لاختبار أثر إدارة الموارد البشرية الخضراء على المهارات

\begin{tabular}{|c|c|c|c|c|c|c|c|}
\hline المنوية. مستوى & $\begin{array}{c}\text { T المصسوبة } \\
\end{array}$ & $\begin{array}{c}\text { التحديدمل } \mathbf{R}^{2} \\
\end{array}$ & $\begin{array}{c}\text { قييتا } \\
\text { Beta }\end{array}$ & المعياري & 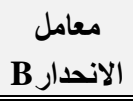 & الأبعاد & p \\
\hline 0.000 & $* 23.769$ & 0.643 & 1.209 & 0.026 & 0.618 & التوظيف الأخضر & 1 \\
\hline 0.000 & *9.096 & 0.300 & 2.108 & 0.031 & 0.282 & التدريب والتطوير & r \\
\hline 0.000 & *13.727 & 0.446 & 1.099 & 0.022 & 0.302 & تقييم الأداء & $r$ \\
\hline 0.000 & $* 26.285$ & 0.570 & 1.848 & 0.021 & 0.552 & الإجمالي & \\
\hline
\end{tabular}

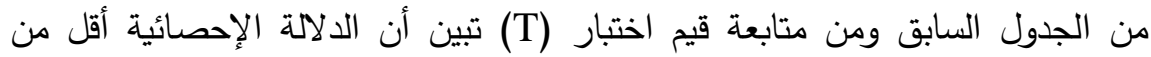

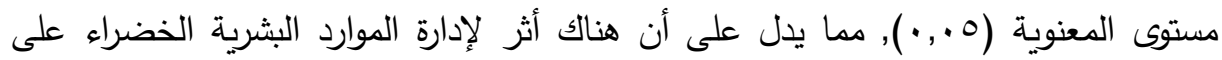

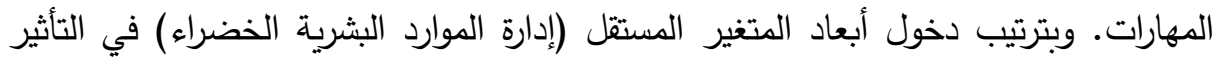

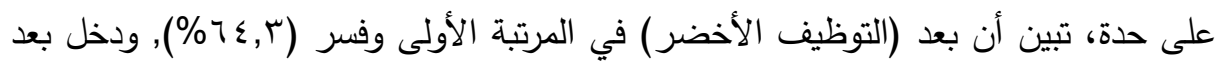

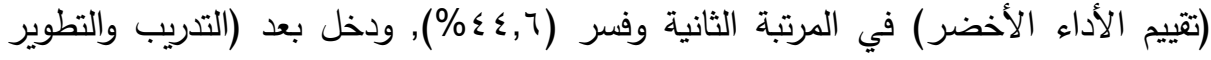

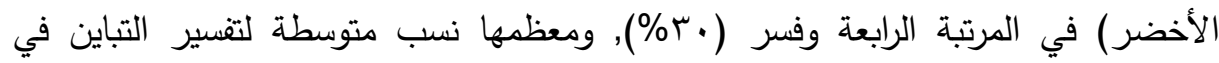
المهارات. وبناء عليه يمكن قبول الفرض, حيث أن: هناك علاقة ارتباط طردية وأثر ذو دلالة إحصائية بين إدارة الموارد البشرية الخضراء والمهارات كأحد أبعاد جدارات العاملين.

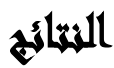

تبين أن الاهتمام بإدارة الموارد البشرية الخضراء بشركة فودافون كان بدرجة مرتفعة, وأن الآراء تتجه نحو الموافقة تجاه عبارات هذا المتغير. وأن أكثر أبعاد إدارة الموارد البشرية الخضراء توافرا من حيث الأهية هي على الترتيب: (التوظيف الأخضر), (التدريب والتطوير التهاه الأخضر), (تقييم الأداء الأخضر ). 
وتبين أن قوة جدارات العاملين بشركة فودافون كانت بدرجة مرتفعة, وأن الآراء تتجه نحو

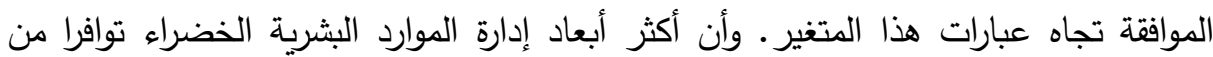
حيث الأهمية هي على الترتيب: (المعرفة), (الصفات), (الدوافع), (المهارات).

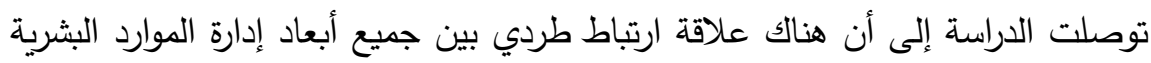

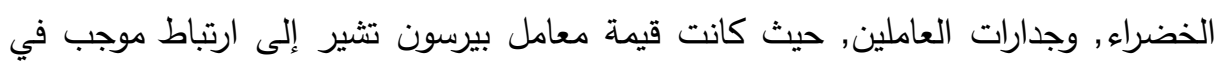
جميع الأبعاد وكانت ترتيبها من حيث قوة الارتباط: (الصفات), (المعرفة), (المهارات),

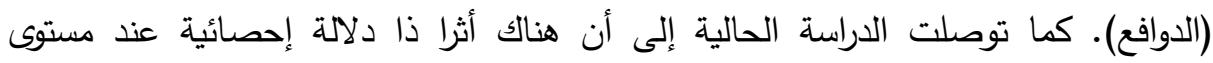
المعنوية (0. . •) لإدارة الموارد البشرية الخضراء في جدارات العاملين بشركة فودافون.

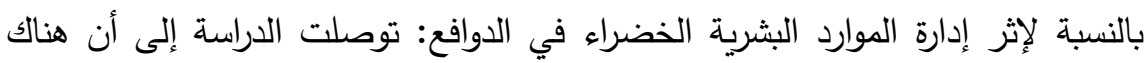

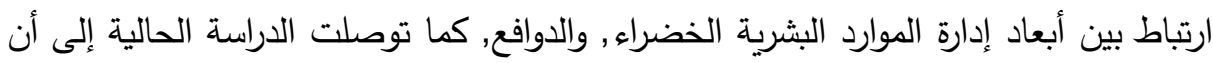
هناك أثرا ذا دلالة إحصائية لإدارة الموارد البشرية الخضراء على الدئردهاء الدوافع في شركة فودافون.

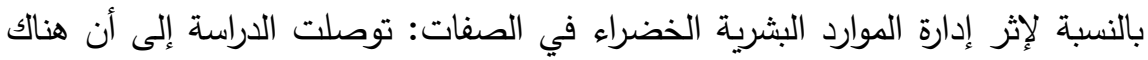

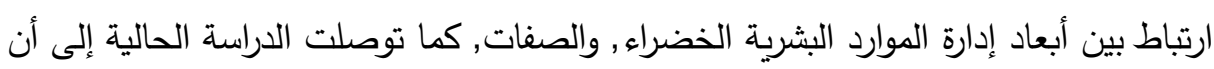

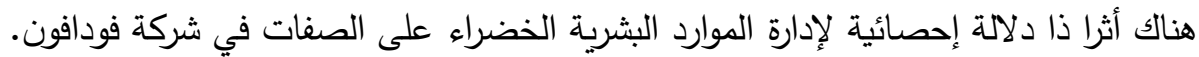

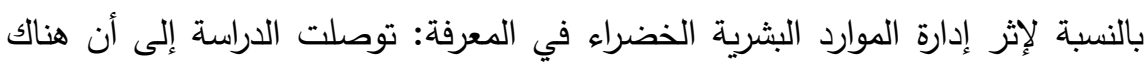

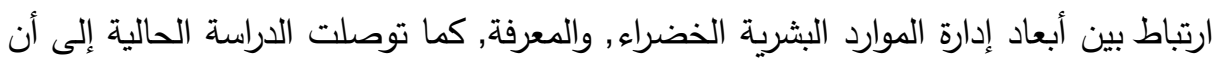

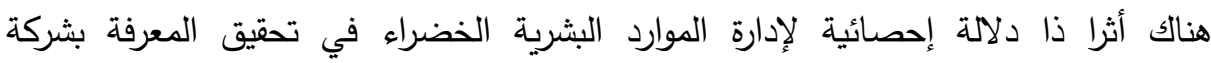
فودافون. بالنسبة لإثر إدارة الموارد البشرية الخضراء في المهارات: توصلت الدراسة إلى أن هناك

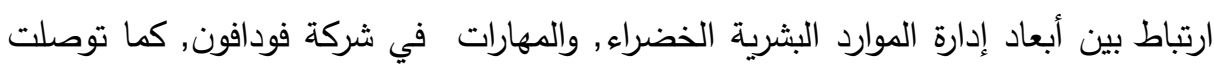
الدراسة الحالية إلى أن هنالك أثرا ذا دلالة إحصائية لإدارة الموارد البشرية الخضراء الخدراء في تحقيق

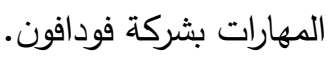

\section{التهوسيايت}


في ضوء النتائج السابقة، يمكن للباحث، تقديم التوصيات التالية:

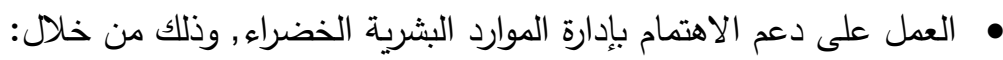

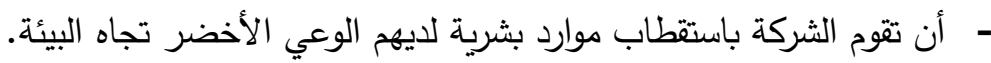
- أن يقوم الموظفون بالثركة بممارسات صديقة للبيئة أثناء العمل. - أن يحرص الموظفون بالثركة على ترشيد الطاقة الكهربائية أثناء العمل. - - أن تقوم الثركة بعمل تدريب مستمر للعاملين بها لرفع الوعي البيئي لديهر. - أن تقوم الثركة بتتفيذ وإتباع النهج الأخضر أثناء أداء الأعمال اليومية. - - أن تقوم الشركة بوضع معايير ومؤشرات لقياس الأداء البيئي على مستوى الشركة.

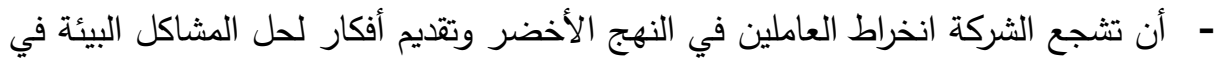
السنوات المقبلة.

$$
\text { العمل على دعم الاهتمام بجدارات العاملين, من خلال: }
$$

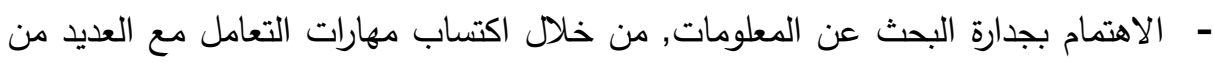
مصادر المعلومات والدعرفة, وخاصة في ظل توافر الإمكانيات التكنولوجية الحديثة.

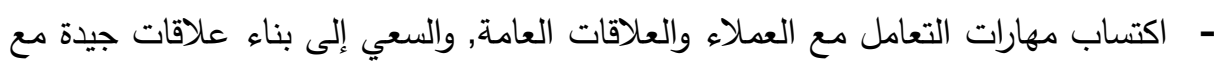
العملاء لتحقيق متطلباتهم. - تتمية القدرة على التعرف على الإجراءات واللوائح غير المعلنة المرتبطة بالعمل, وتفهر الإطار غير الرسمي لسير العمل. - اكتساب مهارات القيادة التي تعمل على دعم ذوي الأداء المرتفع, واستبعاد ذوي الأداء الضعيف عند الضرورة, ومن خلال امتلاك شخصية قيادية جاذبة. - الاهتمام بجدارة التفكير الإدراكي من خلال اكتساب القدرة على النظرة الثاقبة المستقبلية بالاستفادة من الدروس الماضية ومتطلبات الحاضر , والعمل على التتبؤ بالمشاكل المحتملة 


$$
\begin{aligned}
& \text { مجلة العلوم البيئية } \\
& \text { معهد الدراسات والبحوث البيئية - جامعة عين شمس } \\
& \text { أحمد محمد عبد المنعم وآخرون }
\end{aligned}
$$

ومحاولة تجنب الوقوع فيها, والقدرة على رؤية الفروق الجوهرية بين الأحداث الراهنة

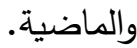

- الاهتمام بجدارة المرونة من خلال اكتساب القدرة على التكيف بسهولة مع المتغيرات في

\section{adt}

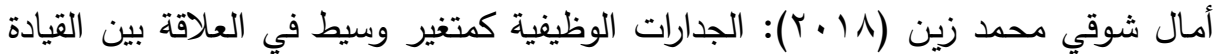

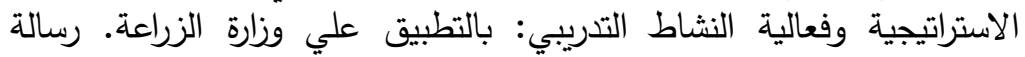

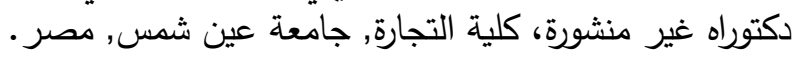

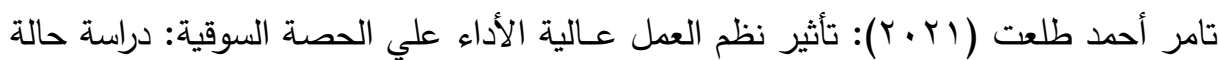
شركة فودافون مصر , رسالة دكتوراه غير منشورة, كلية التجارة وإدارة الأعمال,

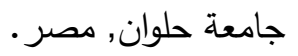

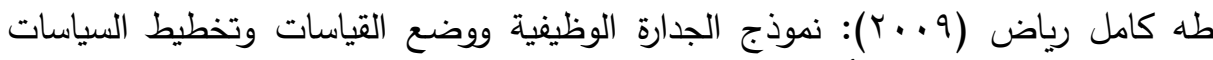

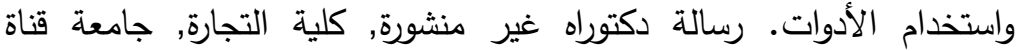

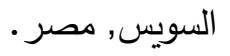

عمار فتحي موسى إسماعيل, ومحمود فوزي أمين البردان: دور ممارسة إدارة الموارد البشرية الخضراء في تدعيم سلوكيات المواطنة التنظيمية البيئية: دراسة البردية تطبيقية.

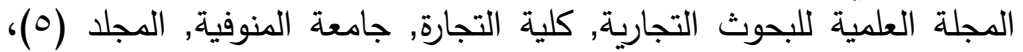

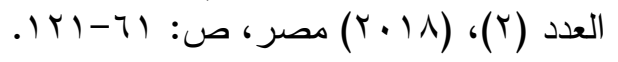

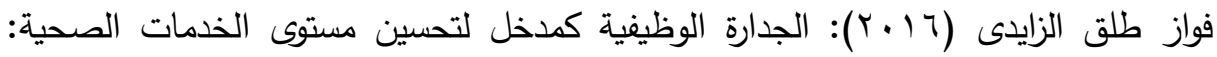

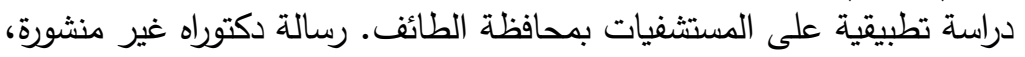

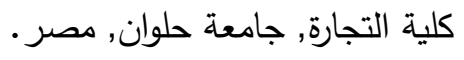

لايل سبنسر، وسيجان سبنسر (999 (1): الجدارة في العمل: نماذج للأداء المتفوق. ترجمة:

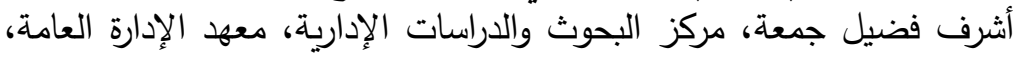

$$
\text { الرياض، السعودية. }
$$

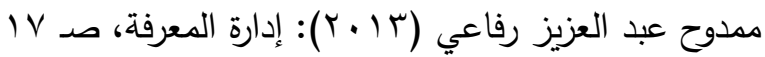

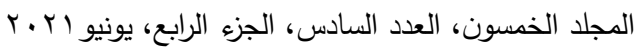

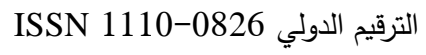


محمد حسن عبده عرنوس (19 (r): أثر إدارة الموارد البشرية الخضراء على التطوير

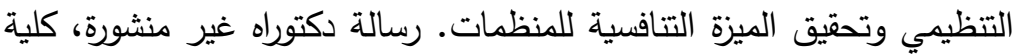
التجارة, جامعة عين شمس, مصر .

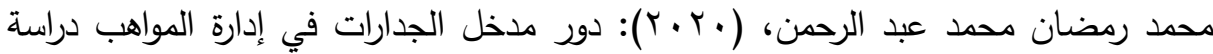

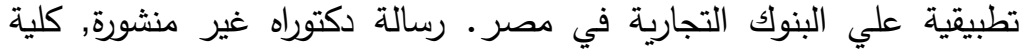

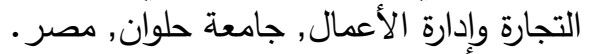

مناف عبد المطلب أحمد: أثر ممارسات إدارة الموارد البشرية الخضراء فماء في تحسين أداء

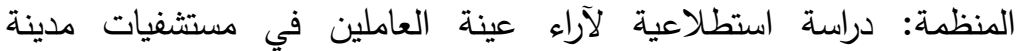

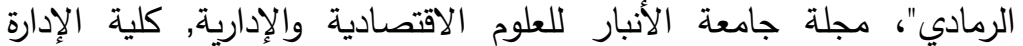

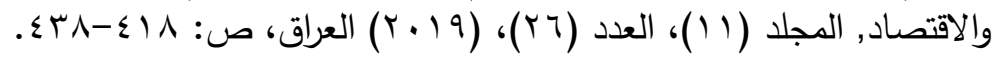

ياسمين عبد الرحيم سيد أحمد (1 ا • ؟): دور المنظمة المتعلمة في اكتساب الجدارات الوظيفية وتحقيق الالتزام التنظيمي: دراسة تطبيقية على قطاع البنوك التجارية. رسالة

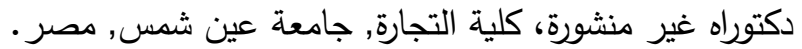

Masri, Hiba Awad (2016): Assessing Human Resources Management Practices in West Bank: An Exploratory Study, Degree of Master of Engineering Management. Faculty of Graduate Studies, Al- Najah National University, Nablus, Palestine.

Mousa, Sharifa K., and Othman, Mohammed: The impact of green human resource management practices on sustainable performance in healthcare organizations: A conceptual framework. Journal of Cleaner Production, Vol. (243), (2021) Article 118595.

Safavi, Homayoun Pasha, and Bouzari, Mona: The association of psychological capital, career adaptability and career competency among hotel frontline employees", Tourism Management Perspectives, Vol. (30), (2019) P: 65-74

ShavangRen, Guiyao Tang and Susan E. Jackson (2017): Green human resource management research in emergency, A review and future directions, Vol. 32, P. 1-35.

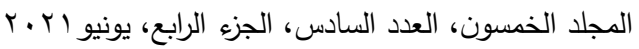

$$
\begin{aligned}
& \text { الترقيم الدولي 0826-0 }
\end{aligned}
$$




$$
\begin{aligned}
& \text { مجلة العلوم البيئية } \\
& \text { معهد الدراسات والبحوث البيئية - جامعة عين شمس لبن } \\
& \text { أحمد محمد عبد المنعم وآخرون }
\end{aligned}
$$

Sienkiewicz, Łukasz, (2014): Competency-based Human Resources Management: The Lifelong Learning Perspective. Educational Research Institute, by the European Social Fund, Warsaw, Poland.

\title{
THE EFFECT OF GREEN HUMAN RESOURCES MANAGEMENT ON ENHANCING THE COMPETENCIES OF VODAFONE EGYPT EMPLOYEES
}

\author{
Ahmad M. Abdel Moneim ${ }^{(1)}$; Mamdouh A. Rifai ${ }^{(2)}$ \\ and Amjad H. Abdel Rahman ${ }^{(2)}$ \\ 1) New line Company 2) Faculty of Commerce, Ain Shams University
}

\begin{abstract}
The objective of the study is to identify the impact of human resources management on enhancing the competencies of workers in the organization, as it shows the concept of green human resources management and the extent of its perception by the human resources in the organization and it also provides some recommendations and proposals for administrative leaders regarding the importance of activating the role of human resources. Green to achieve sustainability. This study relied on the descriptive and analytical approach. The study population is composed of Vodafone employees, and a sample of 300 individuals was obtained. The study relies on collecting data on the survey list.
\end{abstract}

$$
\begin{gathered}
\text { المجلد الخمسون، العدد السادس، الجزء الرابع، يونيو الت الترقيم الدولي 0826-110 } \\
\text { ISSN 110 }
\end{gathered}
$$




$$
\begin{aligned}
& \text { مجلة العلوم البيئية } \\
& \text { معهد الدراسات والبحوث البيئية - جامعة عين شمس لبن }
\end{aligned}
$$

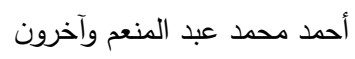

The study concluded that there is a fundamental relationship between managing green human resources and enhancing the competencies of workers, and the study revealed that there is a fundamental relationship between the dimensions of green human resources management on the dimensions of employees' competencies.

The study recommended work to promote the concept of green human resources and enhance the concept of administrative competencies.

Keywords: Green human resources, human resource management, employee competencies, competencies concept, Vodafone. 